\title{
Representativeness of the groundwater monitoring results in the context of its methodology: case study of a municipal landfill complex in Poland
}

\author{
Dominika Dąbrowska ${ }^{1}$ Andrzej Witkowski ${ }^{1} \cdot$ Marek Sołtysiak $^{1}$
}

Received: 23 January 2018 / Accepted: 27 March 2018 / Published online: 2 April 2018

(c) The Author(s) 2018

\begin{abstract}
A representative monitoring of groundwater quality is the basis for a reliable assessment of the impact of pollutant sources on groundwater. This is especially the case in the area around old closed landfills. A study of different methods of groundwater sampling was conducted at a municipal landfill site in Tychy-Urbanowice (southern Poland). The study compared the results of the electrolytic conductivity values obtained during vertical profiling both before and after purging with a passive bailer. The results obtained from the well volume approach after purging up to nine volumes of stagnant water in the piezometer were also taken into account, as were the results of the purging of water volume equal to the double volume of the filtered part of the piezometer. Particular attention was paid to the nested piezometers. The presented values confirm very large differences in the research results of both the sampling technology and the depth of sampling, the piezometer construction and its lithological profile and in the duration and intensity of the tests carried out. In order to determine the real-time variability of the contamination of the monitored water, the tests should be carried out in the same way and should use a fixed schedule.
\end{abstract}

Keywords Hydrogeology $\cdot$ Groundwater monitoring $\cdot$ Purging $\cdot$ Landfills

\section{Introduction}

In the area of pollution sources, it is necessary to conduct reliable monitoring of groundwater quality, which will allow for the proper assessment of the impact of the facility on the groundwater and the planning of ways to counteracting the negative effects of pollution (Grath et al. 2001; Jousma and Roelofsen 2004; Nielsen 2006; Quevauviller et al. 2009). A well-designed monitoring network should provide representative results of the actual impact of the landfill on the soil and water environment (Witkowski 2008). However, the results of groundwater quality monitoring in the area of pollution sources indicate that, depending on various factors, the data obtained from the measurements may not be representative. The reliability of monitoring is influenced by the selection and location of the piezometers (Gomo et al.

Dominika Dąbrowska

dominika.dabrowska@us.edu.pl

1 Department of Hydrogeology and Engineering Geology, University of Silesia, Będzińska 60, 41-200 Sosnowiec, Poland
2017; Hosseini and Kerachian 2017; Nunes et al. 2004), the depth and length of the filtered zone (Lasagna and De Luca 2016), the sampling technique and preparation of the sample for analysis (EPA 1991).

The type and design of the monitoring point (Nielsen red. 2005) plays a significant role in the monitoring of groundwater quality in the region of landfills. The results obtained from piezometers filtered in the whole thickness of the aquifer may limit the ability to outline the contamination plume (Church and Granato 1996; Elci et al. 2003; McMillan et al. 2014). Moreover, the results of the chemical analyses of samples taken from such boreholes are averaged results that do not reflect the actual status of groundwater quality. It is therefore advisable to conduct multi-level monitoring that allows for the vertical chemical stratification of groundwater. Preventing the vertical flow of water in the piezometer improves the representativeness of the results obtained from the physicochemical analysis of the sample. The vertical flow of water in the piezometer can be prevented by lowefficiency purging, i.e., using a purifying micropump, known in the literature as low flow (Sevee et al. 2000; Witczak et al. 2013). In the case of groundwater monitoring networks in the area of pollution sources, the depth of sampling intervals 
is particularly important in the design of the observation network, as well as in the sampling of water for analysis. This depth should take into account the three-dimensional nature of the aquifer system (Broers 2004; van Geer et al. 2008). Zone sampling also helps to outline the contamination plume (MacFarlane et al. 1983; Mor et al. 2006; Witkowski 2015).

The representativeness of the monitoring is also influenced by the sampling technique, particularly in boreholes. Water sampling should be based on the principle of preservation of the actual composition of the tested aquifer (Popek 2003). Purging is the most commonly used technique for collecting water samples for analysis, but this does not pay attention to the possibility of the mixing of water (Nielsen and Nielsen 2006). The key issue for determining this principle is the number of well volumes purged of the piezometer and the removal of the whole volume of stagnant water. In the case of piezometers with a large volume of water, it is possible to modify the principle of purging two or three water volumes and pumping out the volume of water that is equal to double the volume of the filtered part of the piezometer (Witczak et al. 2013). Studies conducted by Barcelona and Helfrich (1986) show that measurement errors due to variations in the chemical composition of the groundwater during purging can be greater than errors resulting from, for example, the improper construction of a hole or the use of inert material in the construction of the borehole. It is also worth noting that research conducted to date (Powell and Puls 1993; Barcelona et al. 1994; Popek 2003) does not indicate a single rule that determines the optimal number of well volumes for all piezometers.

A mixed method, involving the use of a pump and a bailer for groundwater sampling may cause water mixing, the activation of fine particulate material surrounding the borehole and the dehydration of part of the filter or even its destruction (Robin and Gillham 1987; Pohlmann et al. 1984; Puls and Paul 1995).

Numerous studies (Puls and Paul 1995; Nielsen 1992; Gibs et al. 2000; Nielsen and Nielsen 2006) show that constant control of the water level during purging is necessary to ensure that all of the stagnant water is pumped out.

The aim of this paper is to report the impact of a groundwater monitoring methodology for the assessment of the pollution sources of groundwater quality in the region of landfills. Monitoring was carried out at the site of a municipal complex of landfills in Tychy-Urbanowice (southern Poland). Long-term monitoring studies indicate the negative impact of the old municipal landfill in Tychy-Urbanowice on the quality of the groundwater and the lack of such impact on the new, active landfill. In this context, the proper implementation of monitoring studies-that provide reliable results and enable an assessment of actual trends in groundwater quality in the area of an inactive landfill site-is extremely important. The landfill sites provide an excellent research area for multi-faceted research related to the reliability and representativeness of monitoring results (Dąbrowska et al. 2015, 2016; Witkowski 2009). Although this article deals mainly with the impact of the sampling method on the results of the groundwater quality monitoring, attention has also been paid to additional aspects of the monitoring procedure, such as the construction of the piezometer and its location.

\section{Study area}

The research was carried out in a municipal landfill site located in the eastern part of Tychy, in southern Poland. The landfill complex consists of an inactive part (site I) and two sites, II and III, which form a new landfill (Fig. 1). The total area of the landfills, which includes the three sites and their surroundings, is 12.7 ha. The old landfill was located in a recessed area where construction waste was initially stored. Due to the lack of seals and the negative impact of the landfill on the groundwater, this was closed and reclaimed in 1996 (Witkowski 2006). The reclamation consisted of covering the deposited waste with foil, a layer of soil and grassy vegetation.

The landfill was covered with foil in order to limit the infiltration of precipitation and to prevent the inflow of contaminants collected in the waste. The new landfill (sites II and III) already has the necessary cover system and also a liner system (Trybuła and Zając 2011).

Groundwater monitoring of the Quaternary aquifer has been in operation since 1995. The original monitoring network was created in early 1994 and had 14 piezometers. As a result of numerous reorganizations of the network, consisting of the drilling and removal of several piezometers, the current network comprises 15 piezometers (Fig. 1, Table 1). These piezometers belong to two practically separate monitoring networks.

The first of the groundwater monitoring subsystems in the region of the inactive landfill consists of 11 piezometers. This includes four piezometers with long filters $(7-10 \mathrm{~m})$ that cover the whole thickness of the aquifer (P2, P8, P10, P16-one filter section-and P9-two filter sections separated by an interfilter pipe $0.5 \mathrm{~m}$ in length), one piezometer with two filter sections covering the upper $(1.3 \mathrm{~m})$ and lower $(2.2 \mathrm{~m})$ parts of the aquifer and separated by an interfilter pipe $8 \mathrm{~m}$ in length (P1), one piezometer located on the top of the landfill (P18) and two pairs of nested piezometers (P17 and P17A and P19 and P19A) located in separate boreholes. The nested piezometers have short screens $(1-2.5 \mathrm{~m})$ that are located at the top (P17 and P19) and at the bottom (P17A and P19A) of the aquifer (Fig. 2, Table 1).

The second subsystem functions within the local groundwater quality monitoring of the active landfill and has 
Fig. 1 Map showing study area (following: Dąbrowska 2012; modified)

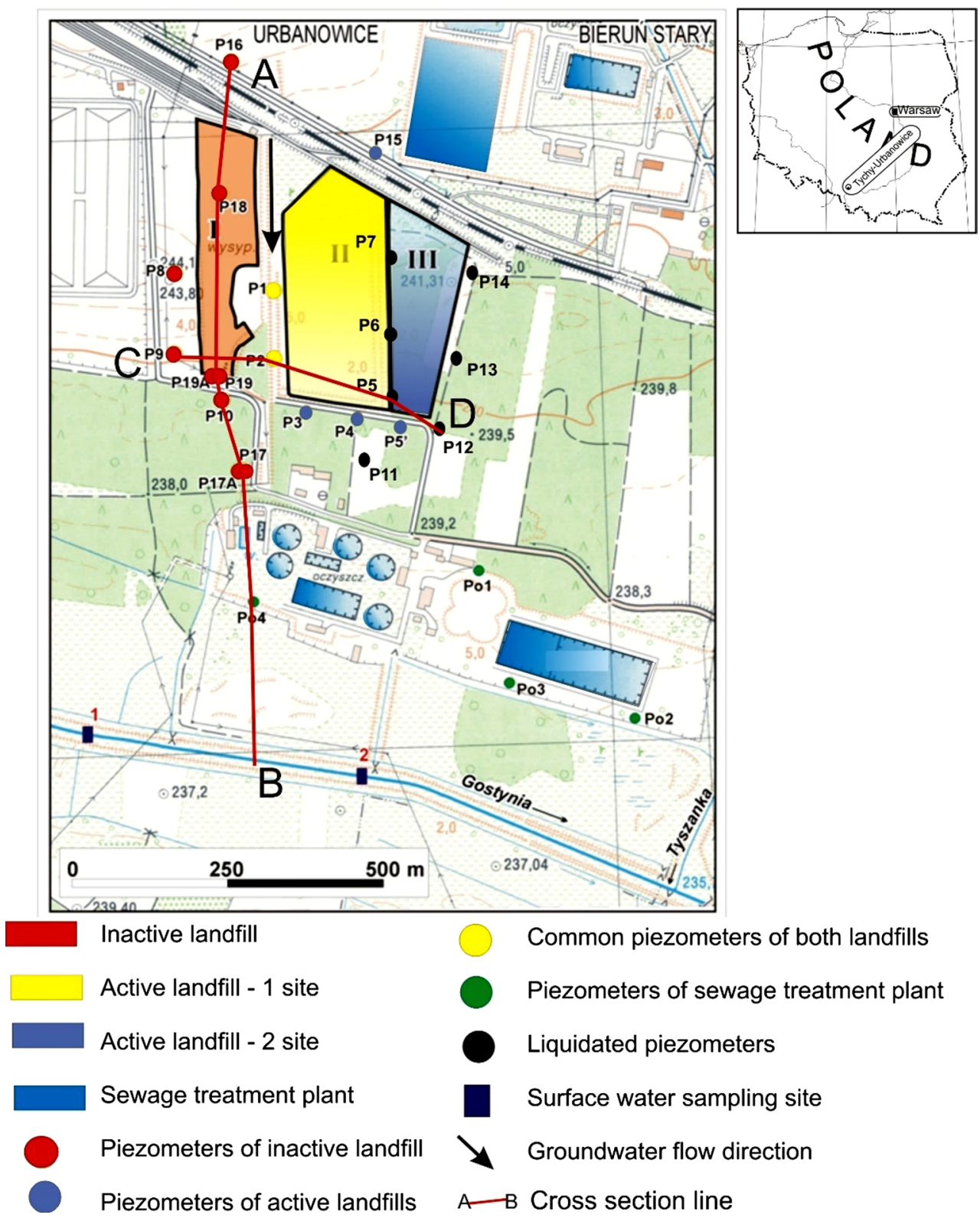

only seven piezometers-P1, P2, P3, P4, P5, P15 and P16 (Dąbrowska et al. 2016). Both subsystems consist of P1 and $\mathrm{P} 2$ piezometers that are located between the active and inactive landfill sites (Fig. 1).

The research area is located in the range of the Upper Silesian Coal Basin, within the vicinity of the Carpathian Foredeep, which is filled with molascent sediments of the Miocene Epoch. The upper part of the Upper Carboniferous (productive) in this region contains layers from the Upper Silesian sandstone series. Locally, on the Upper Carboniferous, there are eroded patches of Triassic formations, which are the remains of Mesozoic sediments from the Silesian Triassic (Witkowski 2015).

The Quaternary (Pleistocene), Triassic (locally) and Carboniferous aquifers can be distinguished in the hydrogeological profile of the area. Locally, groundwater is also present in the interbeddings of sands or the sandstones of the clays of the Miocene. The Quaternary aquifer is the most important. There are very poorly permeable sediments of $80 \mathrm{~m}$ thickness (gray Miocene clays) in the Quaternary aquifer base (Czerminski 1993) that protect the lower Triassic and Carboniferous aquifers (Witkowski 2015). The Quaternary aquifer is locally separated by poorly permeable sediments (Fig. 2).

The groundwater flows in a southerly direction in the research area (Fig. 2). According to the conducted model research, the Gostynia River is the basis for the drainage of $95 \%$ of the groundwater volume (Sitek et al. 2010). The water table within the Quaternary aquifer is mostly unconfined, and, according to the results of the measurements from 
Table 1 Characteristics of the selected piezometers

\begin{tabular}{|c|c|c|c|c|}
\hline Piezometer & $\begin{array}{l}\text { Screen intervals with } \\
\text { lithology [MBGL] }\end{array}$ & Location & $\begin{array}{l}\text { Water table [MBGL]/well } \\
\text { depth in } 2008[\mathrm{MBGL}]\end{array}$ & $\begin{array}{l}\text { Water } \\
\text { column } \\
\left(\mathrm{dm}^{3}\right)\end{array}$ \\
\hline $\mathrm{P} 1$ & $\begin{array}{l}5.0-6.3-\mathrm{fs} \\
14.3-16.5-\mathrm{g}\end{array}$ & $\mathrm{E}$ & $6.1 / 15.0$ & 70 \\
\hline $\mathrm{P} 2$ & $\begin{array}{l}5.0-7.5-\mathrm{fs} \\
7.5-8.2-\mathrm{g} \\
8.2-13.5-\mathrm{ls}\end{array}$ & SE & $5.3 / 12.0$ & 53 \\
\hline P9 & $\begin{array}{l}4.3-7.5-\mathrm{ls} \\
8.0-10.2-\mathrm{us} \\
10.2-12.6-\mathrm{g} \\
12.6-15.5-\mathrm{us}\end{array}$ & SW & $5.1 / 15.6$ & 84 \\
\hline $\mathrm{P} 10$ & $\begin{array}{l}4.2-6.2-\mathrm{fs} \\
6.2-13.8-\mathrm{us} \\
13.8-14-\mathrm{g}\end{array}$ & $\mathrm{S}$ & $4.43 / 13.0$ & 74 \\
\hline P17 & $6.0-7.0-\mathrm{ms}$ & $\mathrm{S}$ & $3.3 / 7.6$ & 8.5 \\
\hline P19 & $6.5-8.5-\mathrm{ms}+\mathrm{ls}$ & $\mathrm{S}$ & $6.3 / 8.5$ & 4.3 \\
\hline P17A & $10.0-12.0-\mathrm{ms}+\cos$ & $\mathrm{S}$ & $3.3 / 13.4$ & 26 \\
\hline P19A & $11.8-13.8-\mathrm{ms}+\cos$ & $\mathrm{S}$ & $6.4 / 14.36$ & 16 \\
\hline
\end{tabular}

cos coarse sands, $m s$ medium sands, $f s$ fine sands, $l s$ loamy sands, $u s$ unsorted sands, $g$ gravels
2016 , it is located at a depth of about $2.5 \mathrm{~m}$ in the region of the P15 piezometer and up to about $8.2 \mathrm{~m}$ in the region of the P8 piezometer (Witkowski 2016). The water table is confined locally, and in the case of the P18 piezometer it is located at the top of an inactive landfill, stabilized at a depth of $11.7 \mathrm{~m}$. The seasonal fluctuations of the groundwater table are small, $30 \mathrm{~cm}$ on average. This fact significantly influences the general constraints of seasonal hydrodynamic changes in the study area.

\section{Materials and methods}

Obtaining representative results for the chemical composition of groundwater relies on appropriate sampling technology. The principle that the sampling water should represent the actual composition of the aquifer (Witczak et al. 2013) should be followed. In hydrochemical conditions that change very little, it is possible to obtain a spatiotemporal representative sample of water, i.e., a sample taken from a particular depth and time (Witkowski 2008), which will fully characterize the groundwater environment. This is a more difficult task in the case of areas affected by pollution sources (e.g., landfills) and characterized by high temporal and spatial variations in the mass flow of aquifers (Witkowski 2009).

The general rule of groundwater sampling is to, at least, remove the double volume of water that is stagnating in the well (Witczak et al. 2013). Water stagnating in a well is subject to various physicochemical processes that may have a negative impact on the representativeness of the water sample (Herzog et al. 1991). However, there is no clear indication that the principle of removing the double well volume is valid at every point (the well, the piezometer) or whether two volumes are sufficient in every case. It is commonly assumed that three water volumes should be purged, provided that the field parameters are stable (Martin-Hayden 2000; Qi et al. 2017; Zdechlik et al. 2013). An alternative assumption is proposed by Witczak et al. (2013), that in the case of piezometers, the purged water volume should be equal to at least the double volume of the filtered part of the borehole.

In accordance with the recommendations of the US Office of Surface Mining Reclamation and Enforcement (2012), after purging five volumes of stagnant water in the piezometer it is possible to take a sample of water without stabilizing the physicochemical parameters. Determining that a well has been adequately purged can also be achieved by monitoring at least two field parameters (e.g., pH, temperature, EC, Eh and turbidity). Dissolved oxygen (DO) can also be used as a field parameter but it cannot be used when the well is purged with a bailer.

Detailed guidelines for reading the measurement results that indicate stabilization are:

- the $\mathrm{pH}$ is within 0.1 or 0.2 of a standard unit,

- the temperature is within $0.2{ }^{\circ} \mathrm{C}$,

- the EC is within 5\% for values equal to or less than 100 $\mu \mathrm{S}$ and $3 \%$ for values greater than $100 \mu \mathrm{S}$,

- the DO is within $10 \%$,

- the Eh/ORP (oxidation reduction potential) is within $10 \mathrm{mV}$ and

- the turbidity is within $10 \%$ for values greater than 1 NTU but less than 100 NTUs. 


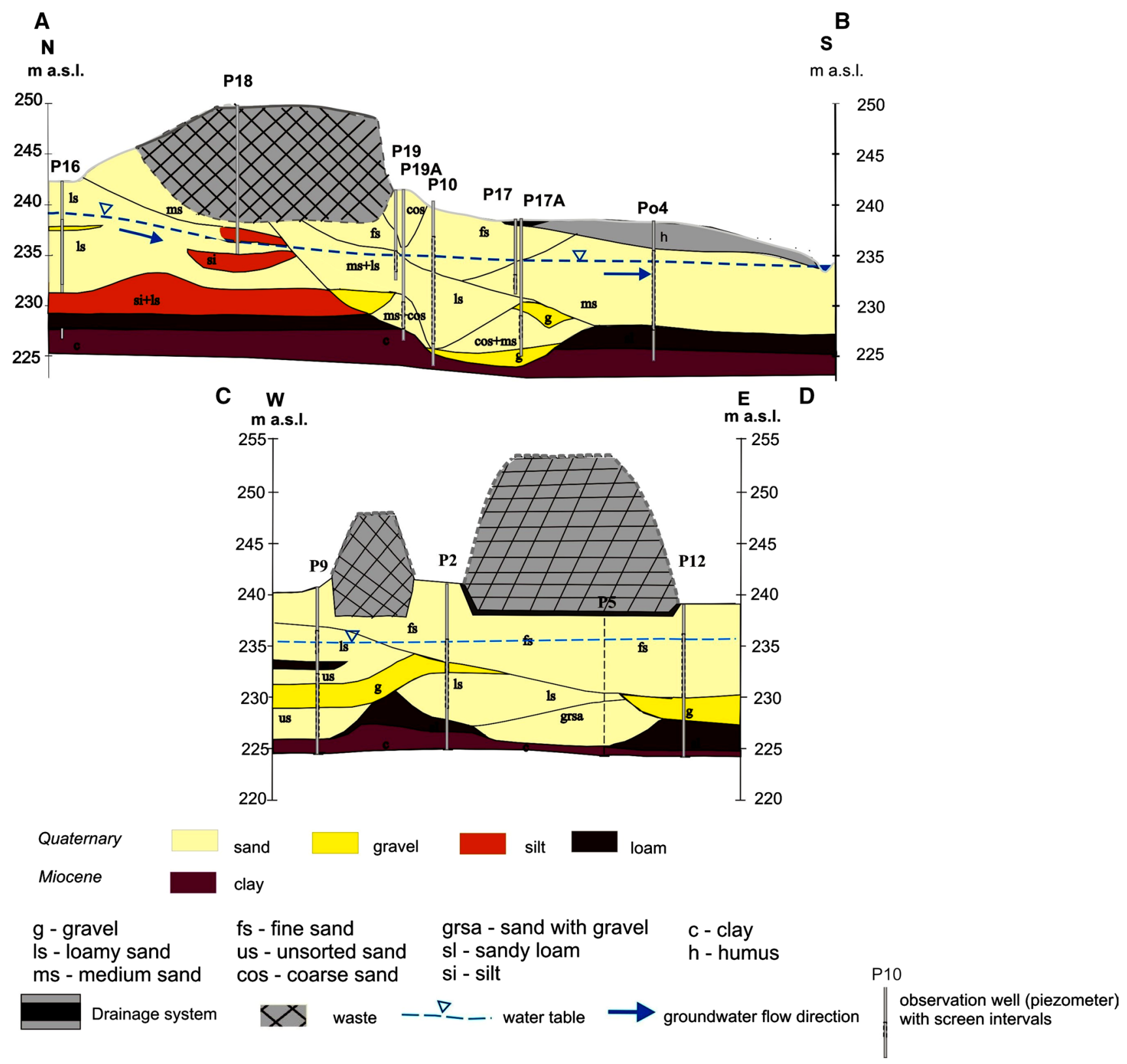

Fig. 2 Hydrogeologic cross sections $\mathbf{a}, \mathbf{b}$ and $\mathbf{c}, \mathbf{d}$. Elevation water table according to the measurements of October 2008

An alternative method to the traditional "well volume" approach that is more commonly used is the low-flow method (Harte 2017; Nielsen 2006; Sevee et al. 2000). This method is considered to be one of the best methods for obtaining a representative sample of water in monitoring studies due to the limited mixing of water in the piezometer during purging. The basic assumption for this type of sampling is the lack of vertical flow in the piezometer. The typical range of discharges for low-flow water purging is $0.5-1 \mathrm{dm}^{3} / \mathrm{min}$. The main advantage of this method is the low turbidity of the sample, which limits the filtration process. In the case of groundwater sampling in the vicinity of pollution sources, where the filter zone of the piezometer may exhibit heterogeneous chemical composition, low-flow pumping may produce results that do not reflect the actual physicochemical properties of the aquifer (McMillan et al. 2014; Witczak et al. 2013). In general, the submersible pumps in Poland (e.g., the MP-1 from Grundfos) are recommended for the sampling of water from piezometers with the removal of three well volumes of stagnant water. For the purpose of this article, an attempt was made to assess the reliability and representativeness of the monitoring results obtained using this methodology. One reason for conducting the study was the problematic representativeness/reliability 
of the results of groundwater quality studies carried out in Poland by various (often the cheapest) contractors in the field of local landfill monitoring (Witkowski 2009; Witkowski and Dąbrowska 2017; Witkowski 2017). The main issue is the problem of complying with the requirement to purge three well volumes of stagnant water. Experience in this regard indicates the frequent violation of this key principle. In order to reduce the time necessary for the monitoring procedure, there is either no removal of stagnant water (primitive samplers are used or water is sampled from different, usually small, depths) or the volume of the removed water is insufficient what is according to weather conditions or the investigator's preferences. As a consequence, a very dangerous situation occurs that results in an unreliable assessment of the chemical status of the monitored groundwater and a poor interpretation of the observed trends. The reliability of monitoring results is particularly at risk in areas where landfill sites have been found to have negative impacts on groundwater. Hydrogeochemical conditions vary in time and space in regions of pollution sources that require a constant and uniform sampling methodology. In the absence of this principle, we are exposed to unrepresentative, unreliable and incomparable results. In this context, the present study aimed to analyze the results obtained using the above-mentioned sampling technique, taking into account a different amount of water being purged of the piezometer (a maximum of 15 well volumes of stagnant water). In addition, the piezometers were sampled (using a bailer) in two ways: (a) before purging (evaluation of vertical hydrogeochemical gradient in water stagnant in piezometer) and (b) after purging and the removal of the recommended volume of stagnant water in the piezometer (assessment of the vertical hydrogeochemical gradient in the aquifer).

In the first stage of the research, tests were concerned with the easily measured groundwater quality indicator, i.e., the electrolytic conductivity (EC). Taking into account the results of the EC studies, a piezometer (P9) was selected in which the monitored groundwater, depending on the current hydrodynamic system, was influenced by the inactive landfill to a greater or lesser degree. The $\mathrm{P} 9$ piezometer has a filter installed on almost the entire aquifer and contains a large volume of stagnant water. Samples were also taken from the P10 piezometer that is located in the outflow of the groundwater where the inactive landfill has a constant influence on the groundwater. The P10 piezometer is also characterized by the filter installed on the entire aquifer and by a large volume of stagnant water. In the cases of the P9 and P10 piezometers, not only were the EC changes evaluated, but the chemical composition of the water sampled from these piezometers was also analyzed at various stages of purging (Fig. 3). These studies began in 2008 (Witkowski 2008) and continued during 2012-2015.
Fig. 3 Research process flowchart

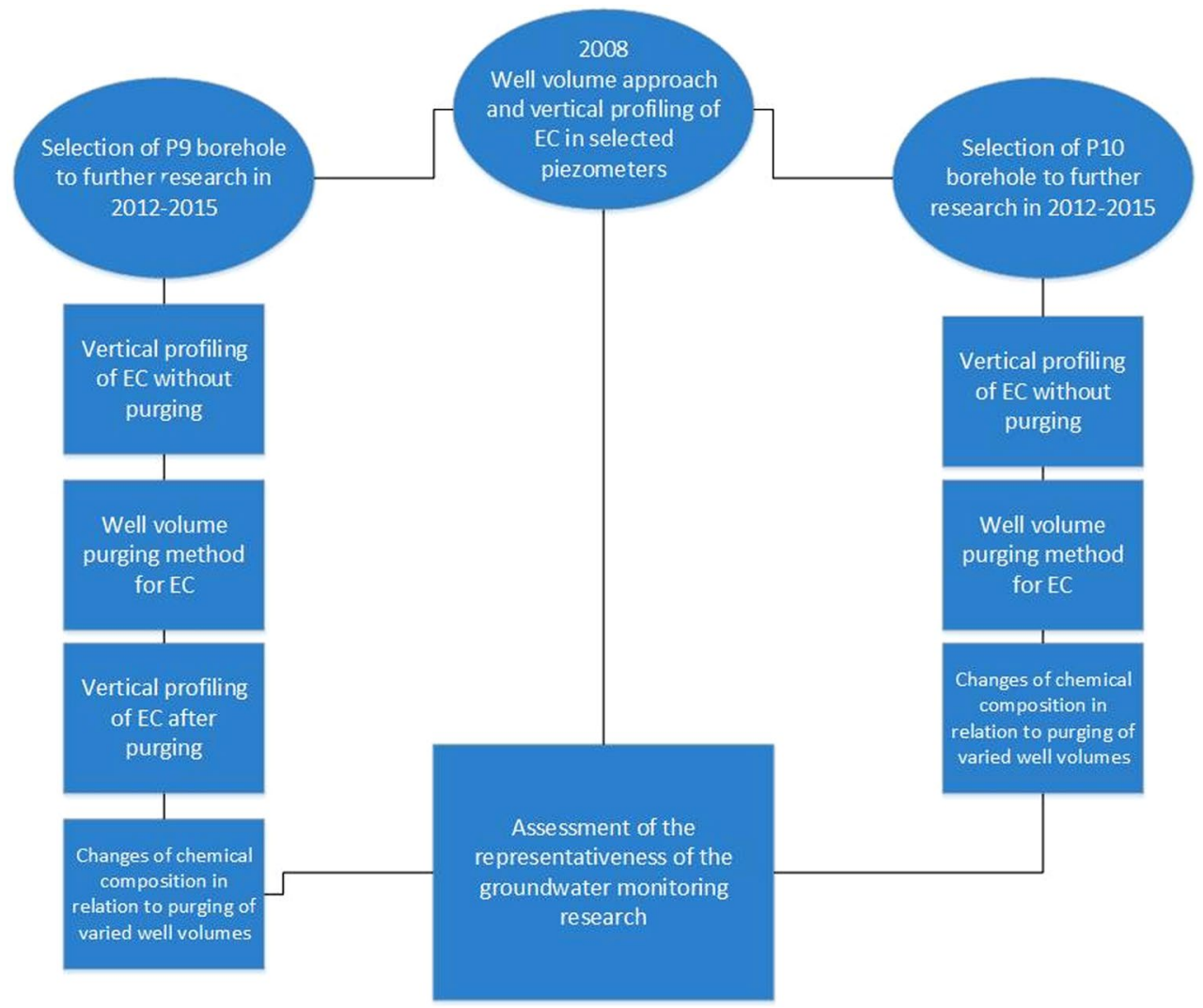


The first stage of the research was conducted in 2008 in the P1, P2, P9, P10, P17, P17A, P19 and P19A piezometers (Fig. 1). These studies included vertical profiling of the electrolytic conductivity of the stagnant water in the piezometers. Tests were conducted using a PVC bailer. The bailer was lowered into the piezometer as slowly as possible to prevent the mixing of the water. For each of the piezometers, a test purging was then performed to remove the volume of stagnant water in the piezometer at which the EC value was stabilized. In order to exclude the effect of atmospheric conditions on the properties of the tested water, the EC measurements were taken in a flow cell, which allows measurements to be made without the water sample coming into contact with air. Sampling was achieved using the Grundfos MP1 pump. This pump is equipped with a spacer ring and a wear ring placed at each impeller, thus eliminating vibration and maintaining pump efficiency. During purging, continuous control of the depth of the dynamic water table in the boreholes was carried out. Single piezometers (with a diameter of $100 \mathrm{~mm}$ ) were pumped at an efficiency of $5 \mathrm{~L} / \mathrm{min}$. Nested piezometers with smaller diameters $(50 \mathrm{~mm})$ were pumped with lower efficiency depending on their depth and the size of the water supply associated with the lithology

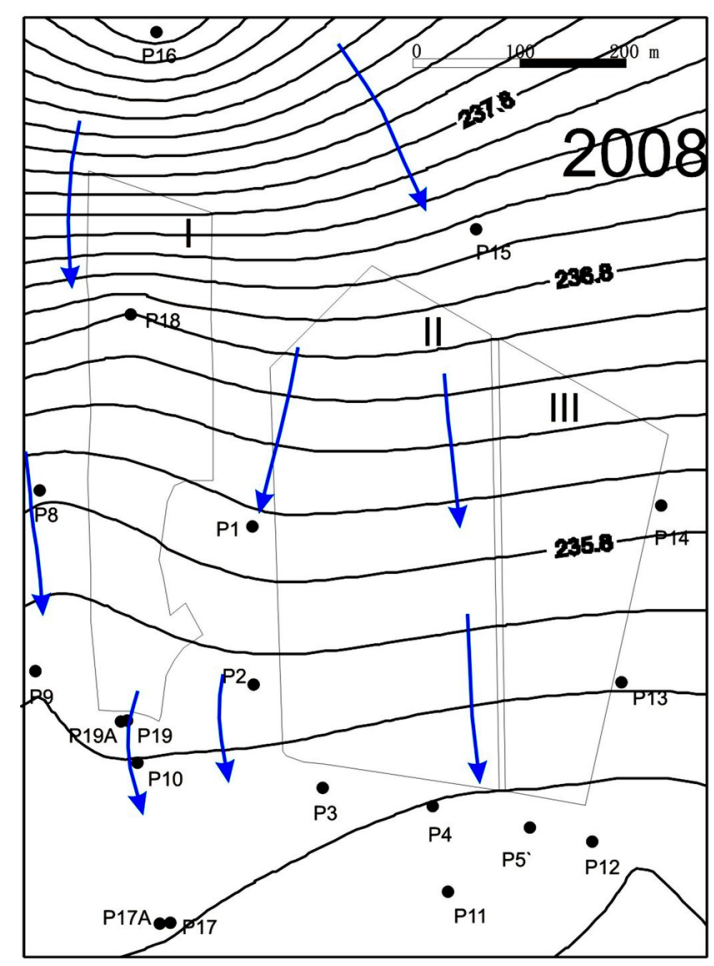

landfills

P10 a piezometer and permeability of the filtered aquifer. The P17 and P17A piezometers were pumped at a rate of $2.5 \mathrm{~L} / \mathrm{min}$, piezometer $\mathrm{P} 19$ at $0.6 \mathrm{~L} / \mathrm{min}$ and piezometer P19A at $4 \mathrm{~L} / \mathrm{min}$. Constant pump efficiency was maintained during the process.

The studies also made it possible to determine the changes of EC values using water volume suggested by Witczak et al. (2013). EC measurements of the pumped piezometers in 2008 enabled the calculation of the amount of water equal to the double volume of the filtered part of the borehole, the determination of the corresponding EC value and comparison of these values with the EC values obtained after purging three well volumes.

The second stage of the study was conducted in 2012-2015. Detailed tests during this period included those carried out in the selected P9 and P10 piezometers. The selection of specific areas was based on the confirmed impact of the landfill on the groundwater within them. Contour maps of both 2008 and 2015 indicate that the P9 piezometer is located in the periphery area (southwest) of the potential impact of the landfill and the P10 piezometer is located in the central (southern) part of the groundwater outflow from the landfill (Fig. 4). Another factor determining the choice of both piezometers was their similar

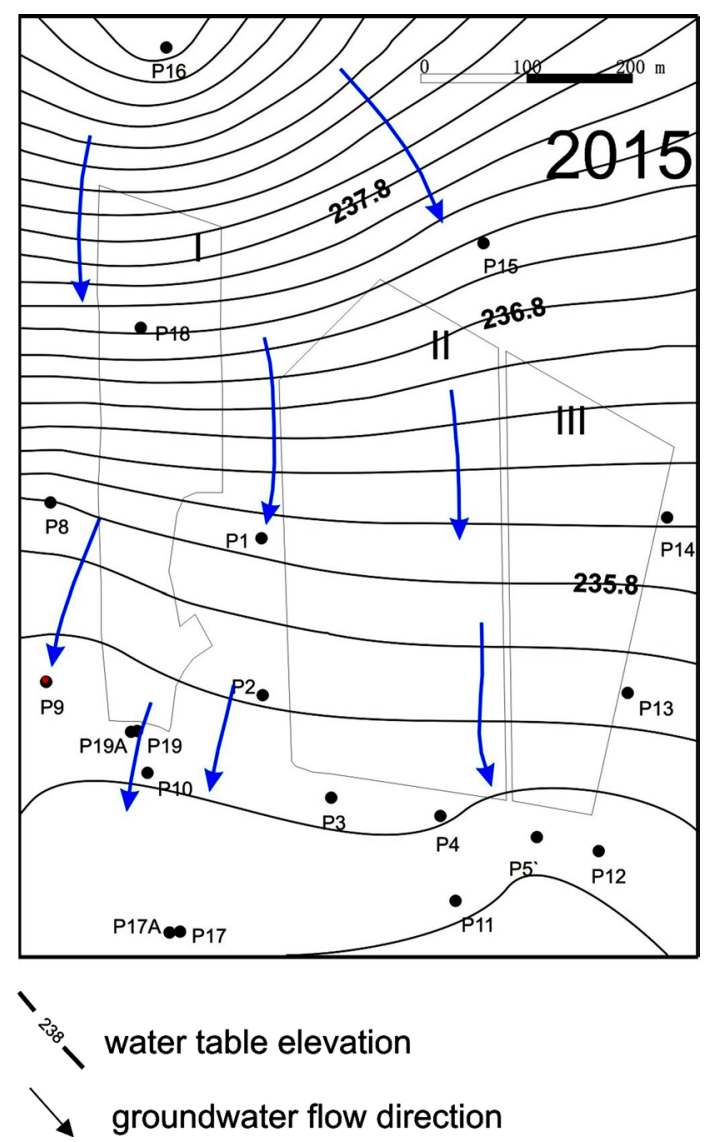

Fig. 4 Groundwater contour maps for 2008 and 2015 
construction-the filter in both piezometers is located within the entire thickness of the aquifer.

During the second stage, the following tests were carried out in the $\mathrm{P} 9$ and $\mathrm{P} 10$ piezometers.

- The EC vertical profiling in stagnant water.

- The EC measurements during purging.

- A study of changes in the chemical composition of the groundwater stagnating in piezometers and following the purging of four well volumes of the water stagnating in them. In both piezometers, the relative stability of both the EC and the chemical composition of the groundwater were noted following the purging of four well volumes.

- The EC vertical profiling in the purged and sampled piezometer following the removal of 12 volumes of water and after the stabilization of the water table ( $\mathrm{P} 9$ piezometer only).

In the assessment of the vertical gradient of changes of the EC values in the water stagnating in the piezometer in 2012-2015, four measurement series for the P9 piezometer and four measurement series for the $\mathrm{P} 10$ piezometer were taken. Measurements were taken using a PVC bailer at four different depths below the flange $(7,10,12$ and $15 \mathrm{~m}$ for the $\mathrm{P} 9$ piezometer and 6, 8, 11 and $14 \mathrm{~m}$ for the P10 piezometer). As in 2008, the sampler was lowered into the piezometer as slowly as possible to prevent water mixing. In addition, for the P9 piezometer, three series of vertical profiles were performed following the so-called "long pumping" (after purging out 12 well volumes) and after waiting for $1 \mathrm{~h}$ for the water table to stabilize. The measurements were taken at the same depth as in the case of a piezometer that was not purged.

The second part of the study entailed the EC value measurements from the $\mathrm{P} 9$ and $\mathrm{P} 10$ piezometers during purging. The EC values were measured using a filter cell, without the water sample coming into contact with the air to prevent any disturbance of the results. Measurements were taken every minute for the first quarter of the measurements, then every 2 min until the parameter was stabilized.

An important element of the second stage of research was the completion of the full physicochemical analysis of the water samples taken from the $\mathrm{P} 9$ and $\mathrm{P} 10$ piezometers in 2015. The tests were conducted with the pump submerged to a depth of about $1 \mathrm{~m}$ above the upper edge of the filter. The first sample was of stagnant water and was taken immediately after the start of purging. Water samples were taken after purging one, two, three and four volumes of water columns in each of these piezometers. The following parameters were determined: $\mathrm{EC}, \mathrm{pH}$, ammonium ion, nitrates, nitrites, boron, zinc, phosphates, bicarbonates, carbonates, magnesium, manganese, copper, nickel, cadmium, general organic carbon, lead, potassium, sodium, iron, chlorides and sulfates.

These tests allowed for the evaluation of the EC and also the chemical composition changes of the tested waters. These were dependent on the purging time and the volume of purged water from the analyzed piezometers, their location and their location relative to the landfill and hydrodynamic system of the aquifer.

\section{Results}

\section{First stage of research}

The number of EC measurements taken during vertical profiling in the piezometers in 2008 varied and ranged from two (P19) to six (P9). This was due to the length of the bailer $(1 \mathrm{~m})$, the varying lengths of the active filter parts and the different heights of the water columns in the piezometers (Fig. 2, Table 1).

The results showed that the EC value increased substantially as the depth of sampling increased. For some piezometers, i.e., P10, P17, P17A and P19, the maximum EC values were found at the maximum sampling depth (Fig. 5b-d). Some maximum EC values were found at the depth of sampling that preceded the deepest sampling (P1, P9 and P19A, Figs. 5a, b, d).

The greatest relative EC increments were found in the $\mathrm{P} 9$, P17A and P2 piezometers (Figs. 5b, c, a). The maximum EC values measured at the lower intervals of these piezometers were 2130,7570 and $2210 \mu \mathrm{S} / \mathrm{cm}$, respectively, and were approximately five to seven times greater than those obtained in the subsurface zone $(311,1320,501 \mu \mathrm{S} / \mathrm{cm})$.

The smallest relative percentage increases of EC were observed in the shallow nested piezometers, P17 and P19 (Fig. 5c, d), and in the deeply nested piezometer, P19A (Fig. 5d). In the cases of the P19 and P19A piezometers located at the foot of the landfill, the vertical gradient in both cases is small and results from the contamination of the water in the whole of the borehole log. In the cases of the P17 and P17A nested piezometers, which are located at a greater distance from the landfill due to the downward migration of the contamination plume, this gradient is much more visible in the deeper piezometer (P17A).

The results clearly show that in the analyzed case, the sampling of groundwater from piezometers without purging and from different depths can lead to completely unrepresentative results.

The purging of piezometers $\mathrm{P} 1, \mathrm{P} 2, \mathrm{P} 9, \mathrm{P} 10, \mathrm{P} 17, \mathrm{P} 17 \mathrm{~A}$, P19 and P19A was carried out in 2008 and was aimed at determining the multiplicity of the stagnant water volume in the piezometer, from which the EC value is stabilized. The assumption was made that stabilizing the EC means 
Fig. 5 Results of vertical profiling of EC in 2008 (using PVC bailer)
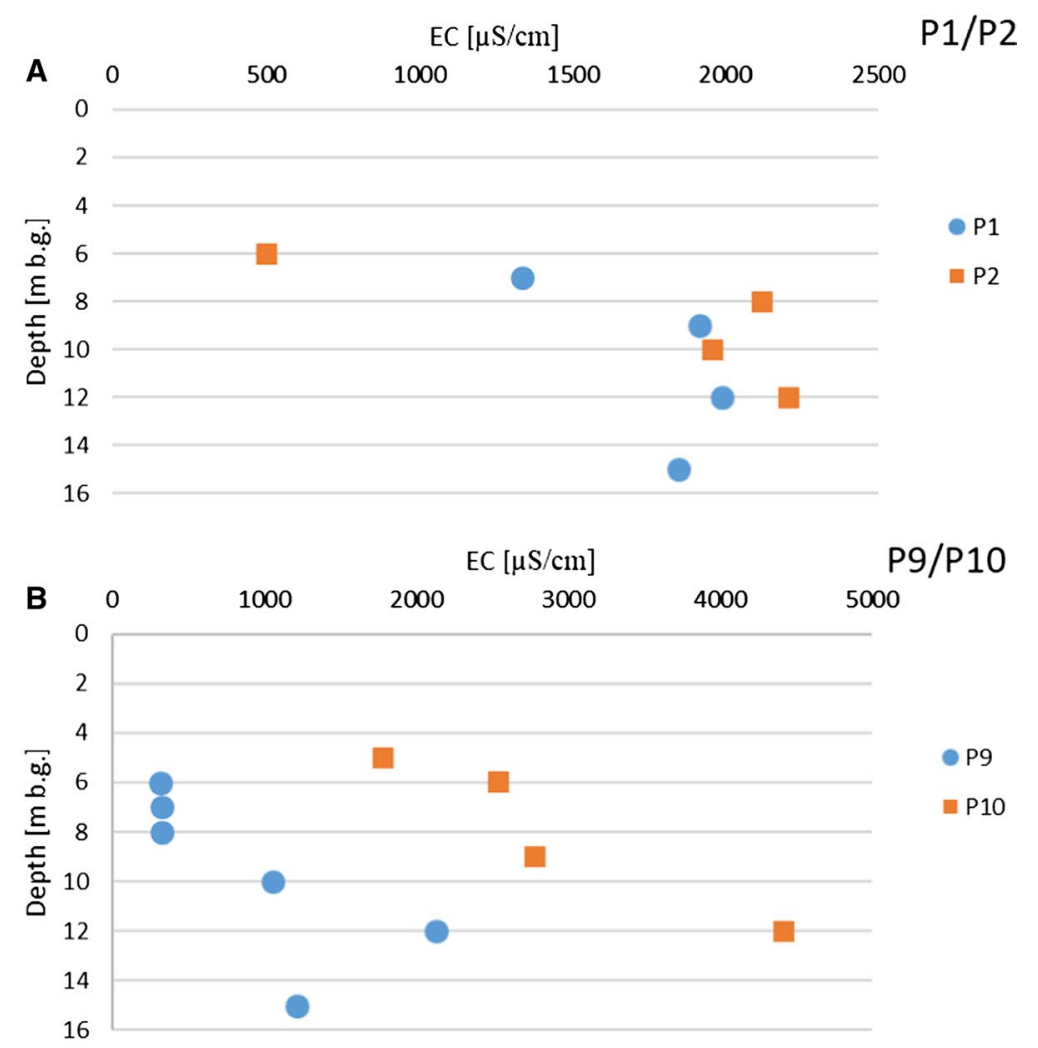

$\mathrm{EC}[\mu \mathrm{S} / \mathrm{cm}]$

P17/ P17A

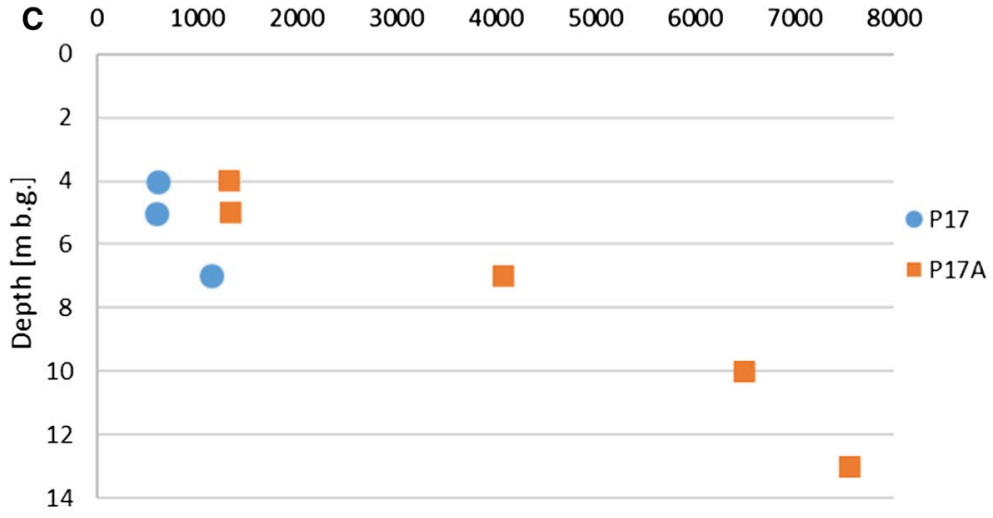

$\mathrm{EC}[\mu \mathrm{S} / \mathrm{cm}]$

P17/ P17A

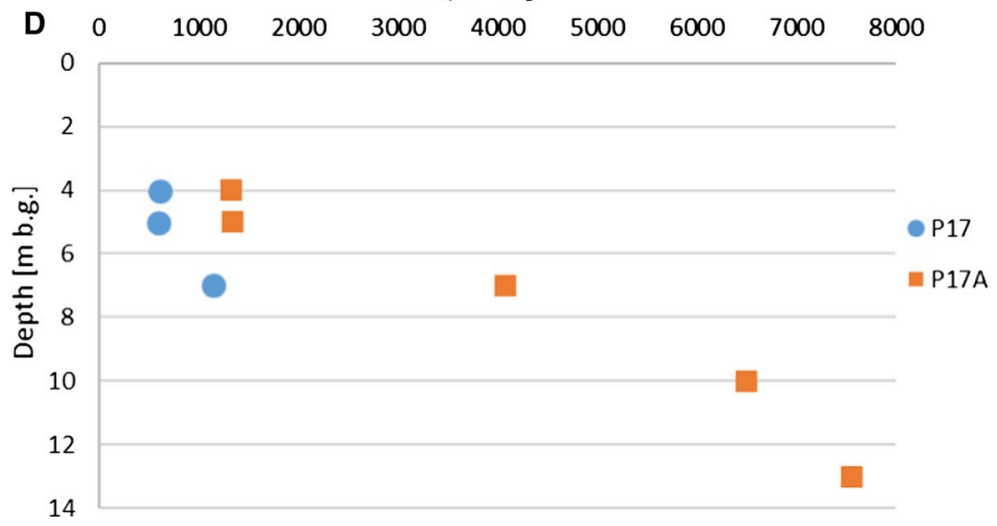


obtaining its constant value in two well volumes successively purged. In the measuring series from 2008, pumped out from four well volumes (P9, P10 and P17A), up to nine well volumes from the P19A piezometer before the stabilization of this parameter was achieved. Different reactions to purging were found in individual piezometers, showing different results in EC temporal changes during purging (Fig. 6a-h). A more detailed analysis of the observed changes indicates that the course of these changes and their scale is different in practically every piezometer. The obtained EC values varied, fluctuating in a relatively narrow range in P17 and P19, from 812 to $925 \mu \mathrm{S} / \mathrm{cm}$ and 1425 to $1591 \mu \mathrm{S} / \mathrm{cm}$, respectively, with large discrepancies from 1470 to $6790 \mu \mathrm{S} / \mathrm{cm}$ found in the P17A piezometer P17A (Table 2).

The dominant group was a group of piezometers in which a more or less systematic increase in EC values was observed (P9, P10, P17A, P19 and P19A) (Fig. 6c-h). When purging began, the $\mathrm{EC}$ values in $\mathrm{P} 9$ and $\mathrm{P} 10$ were relatively stable (at minimum increases) and only after several minutes of purging a significant increasing trend appeared (Fig. 6c, d). During purging, systematic increases in EC size were recorded in piezometers P17A, P19 and P19A (Figs. 6f-h) and the significant difference between them was the rate of stabilization. In P17A, stabilization occurred very quickly and was already underway during the pumping out of the stagnant water (Fig. 6f). In P19, stabilization was found after purging four volumes of water from the piezometer (Fig. $6 \mathrm{~g}$ ) and in P19A stabilization took place only after purging eight volumes (Fig. 6h). Particularly noteworthy are piezometers $\mathrm{P} 1$ and $\mathrm{P} 2$, in which after the initial increase in the EC size in the first purging phase (Fig. 6a, b) there was a systematic decrease in the EC and its stabilization after purging four volumes of stagnant water. It is also interesting that in P1, the EC value after stabilization was close to the value at the beginning of purging (Fig. 6a), while after stabilization in $\mathrm{P} 2$, the $\mathrm{EC}$ value was more than twice the initial value (Fig. 6b). A slight systematic drop in EC size during purging was observed in the $\mathrm{P} 17$ piezometer (Fig. 6e).

The differences in the nature of the changes in the electrolytic conductivity values and their range during the purging of water from the piezometers were the result of the following factors:

- the technical construction of individual piezometers (location of the filter zone for piezometers, their length and diameter),

- the variability of lithology and permeability within the filtered aquifer and

- the location of piezometers in relation to the inactive storage site and the pollution generated by the leachate.

Relatively stable EC values were observed during the entire purging period in the shallow (capturing the upper part of the aquifer), nested piezometers-P17 and P19 (Figs. 2, 6e, g). P17 is located further away from the landfill and during purging, it was infiltrated by shallow unpolluted water. In turn, when purging the P19 piezometer located at the base of the storage site (increasing the impact range), the inflow of more polluted waters may increase.

In contrast to piezometers P17 and P19, a clear increase in water mineralization was noticeable in the case of piezometers P17A and P19A that capture the lower parts of the aquifer (Figs. 6f, h). This increase occurred very quickly and was the results of:

- the location within the contour of the contamination plume and

- the position of the piezometer filters in the contaminated aquifer (less than $10 \mathrm{~m}$ a.g.l).

The analysis of the results of both vertical profiling and purging for piezometers P17 and P17A, as well as P19 and P19A, indicates the importance of the appropriate location of the filter interval in piezometers in the context of assessing the actual impact of the monitored landfill on groundwater.

As already noted, tests carried out in 2008 made it possible to compare the EC values obtained after purging (the generally used) three volumes of stagnant water in the piezometer (3v) with the EC values obtained for the double volume of water column in the filtered zone of the piezometer $\left(2_{\mathrm{vd}}\right)$ (Witczak et al. 2013). The results of the volume calculations, together with the corresponding measured EC value, are summarized in Table 3.

According to calculations, the values obtained during pumping out the reduced water volume $\left(2_{\mathrm{vd}}\right)$ are the closest to the suggested three well volumes in piezometers with one long section of the filter (P2, P10). Larger deviations were observed in piezometers with two filter sections (P1, P9). The biggest differences were found for nested piezometers that capture the lower part of the aquifer (P17A, P19A), which have a short section of the filter at the bottom part of the borehole. In these cases, the volume of water equal to the double volume of the water column in the filtered zone of the piezometer $\left(2_{\mathrm{vd}}\right)$ is between 1.5 (in P9) and 12 (in P1) times smaller than the three volumes of water stagnating in the piezometer $(3 \mathrm{v})$. The obtained results indicate that the method consisting of purging a $2_{\mathrm{vd}}$ volume should not be used in piezometers with a short section of filter and a large thickness of the aquifer or in piezometers with several sections of filter.

\section{Second stage of research}

This research stage, based on more detailed and repeated tests in the selected two piezometers ( $\mathrm{P} 9$ and $\mathrm{P} 10)$, assessed 
Fig. 6 Changes of EC values during well purging
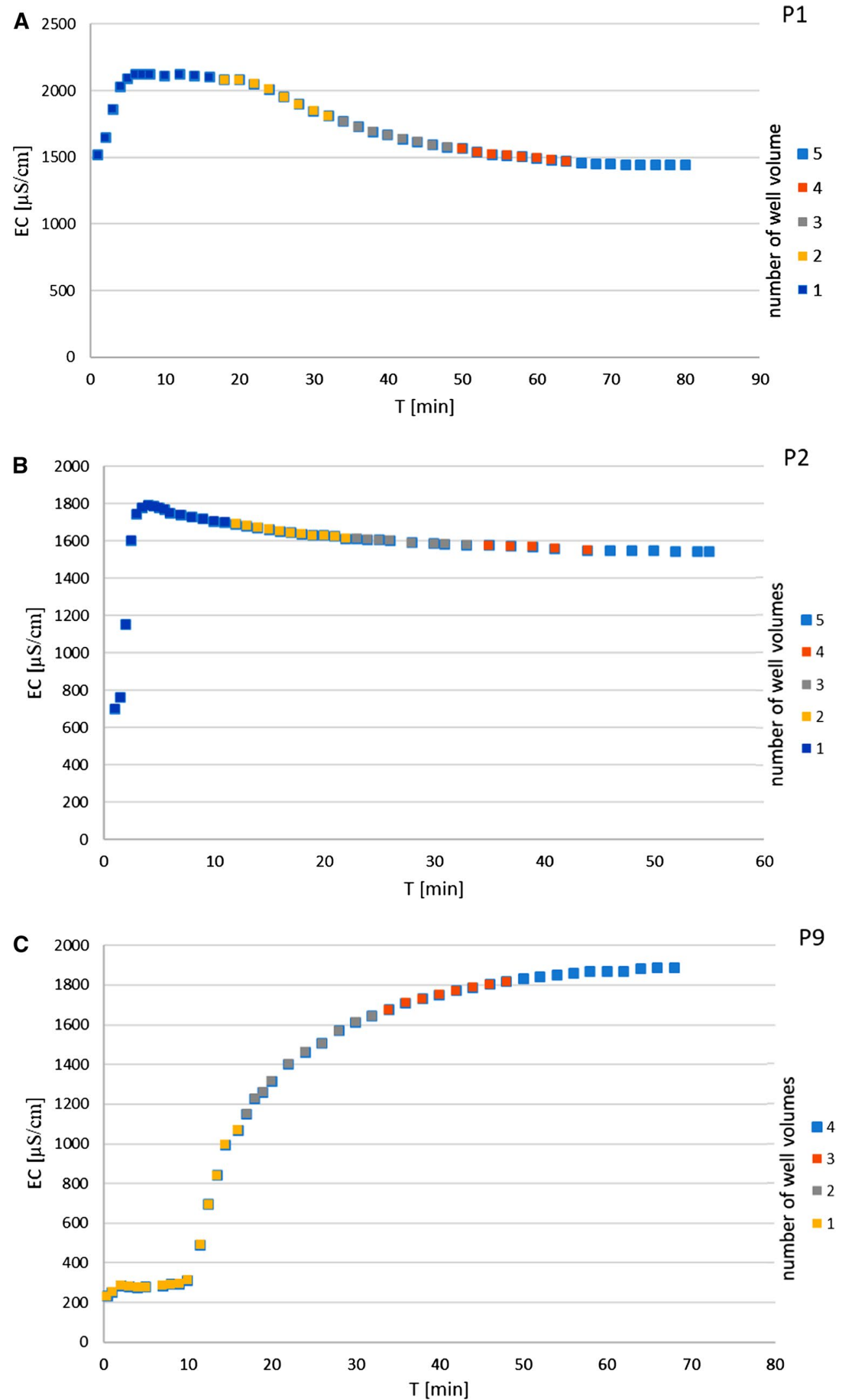
Fig. 6 (continued)
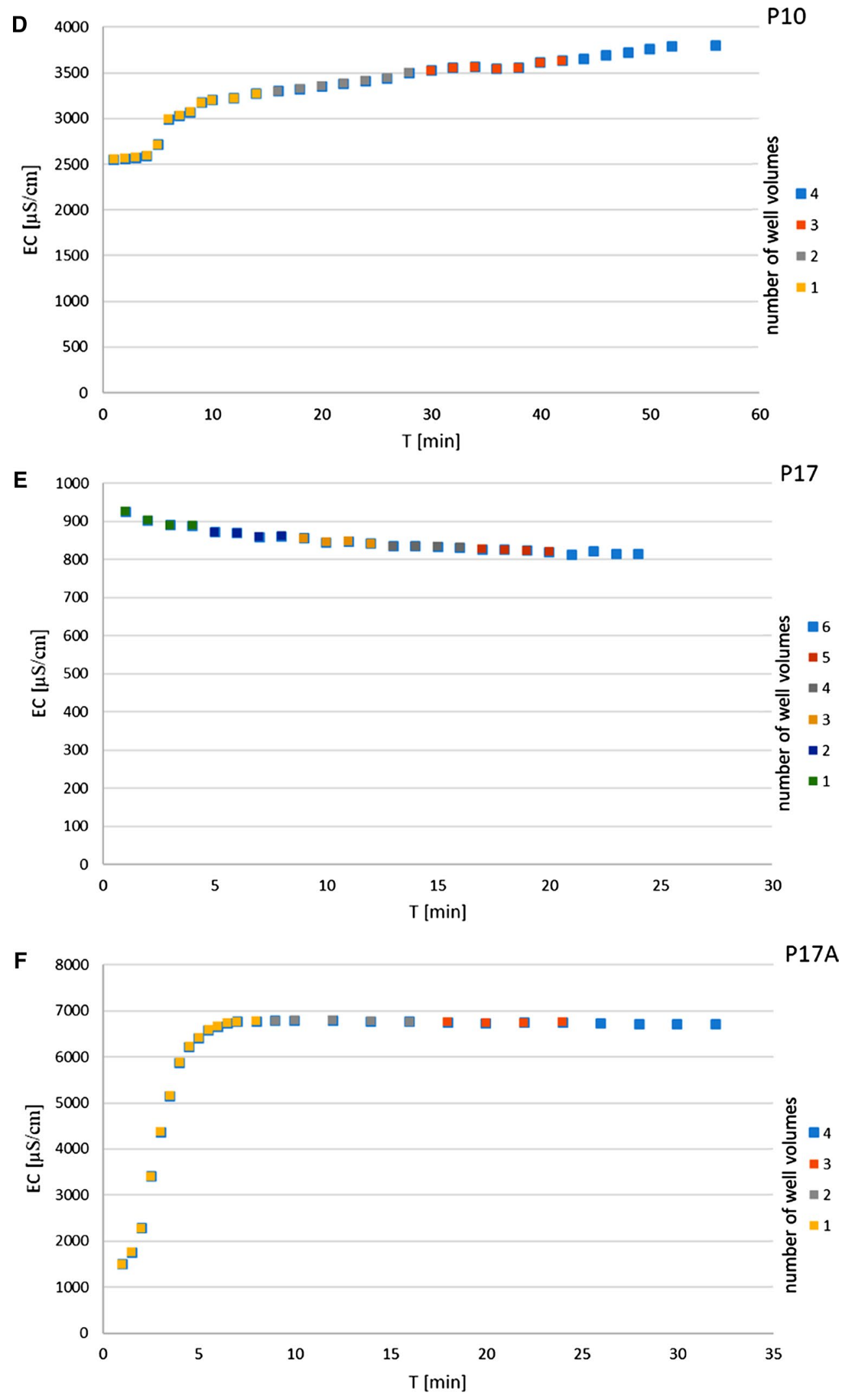
Fig. 6 (continued)
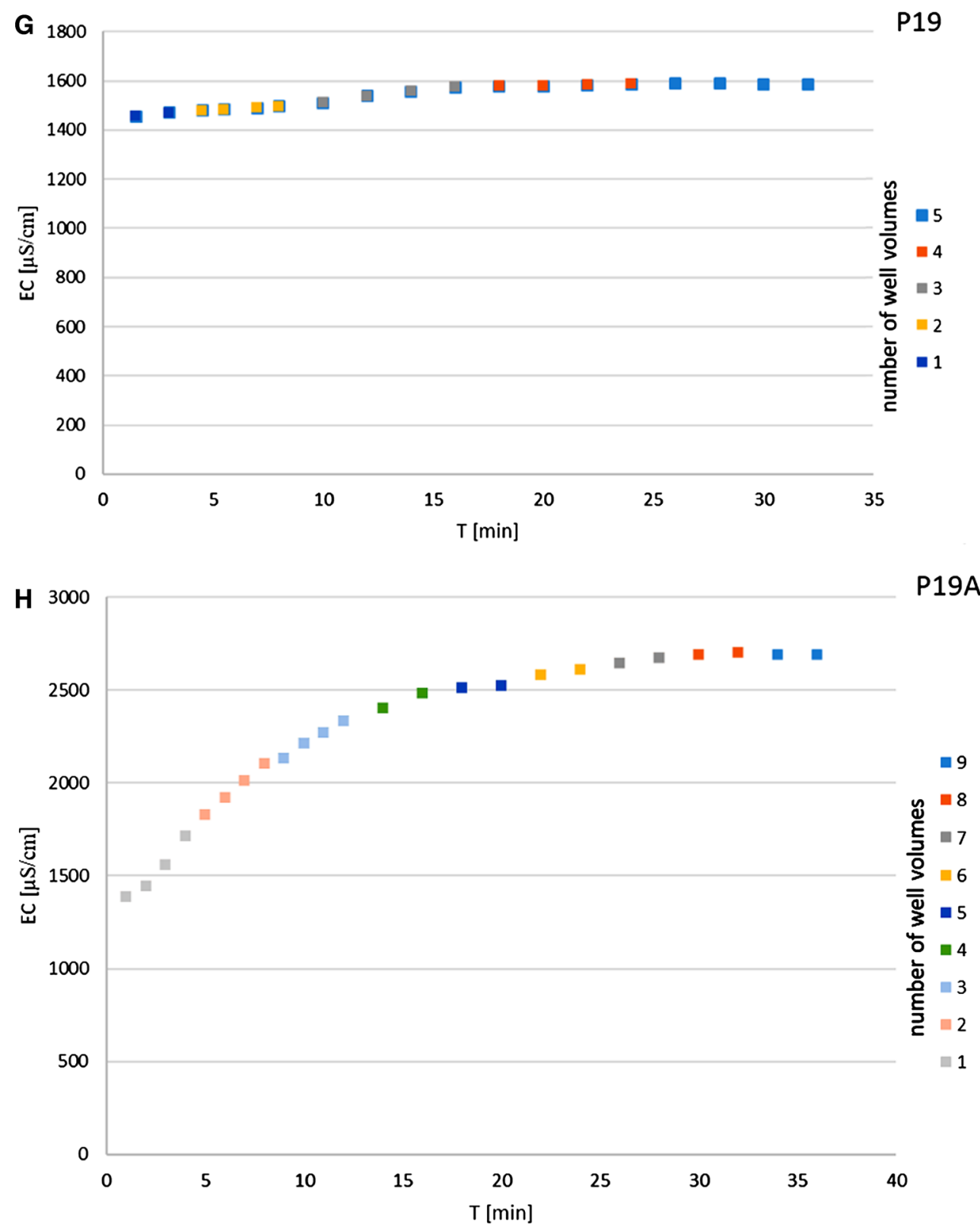

Table 2 Changes of EC values during purging

\begin{tabular}{lcccccc}
\hline Piezometer & Min EC $(\mu \mathrm{S} / \mathrm{cm})$ & Max EC $(\mu \mathrm{S} / \mathrm{cm})$ & $\begin{array}{l}\text { Max-min } \\
(\mu \mathrm{S} / \mathrm{cm})\end{array}$ & $\begin{array}{l}\text { Percentage } \\
\text { increase }\end{array}$ & $\begin{array}{l}\text { EC after removal of 3 } \\
\text { well volume }(\mu \mathrm{S} / \mathrm{cm})\end{array}$ & $\begin{array}{l}\text { Stabilized EC value }(\mu \mathrm{S} / \\
\mathrm{cm}) / \mathrm{number} \text { of well } \\
\text { volume }\end{array}$ \\
\hline P1 & 1442 & 2120 & 678 & 47.02 & 1574 & $1442 / 5$ \\
P2 & 700 & 1790 & 1090 & 155.71 & 1579 & $1544 / 5$ \\
P9 & 232 & 1888 & 1656 & 713.79 & 1817 & $1888 / 4$ \\
P10 & 2550 & 3800 & 1250 & 49.02 & 3630 & $3800 / 4$ \\
P17 & 812 & 925 & 113 & 13.92 & 831 & $814 / 5$ \\
P17A & 1470 & 6790 & 5320 & 361.90 & 6750 & $6710 / 4$ \\
P19 & 1455 & 1591 & 136 & 9.35 & 1574 & $1587 / 5$ \\
P19A & 1383 & 2700 & 1327 & 95.95 & 2330 & $2690 / 9$ \\
\hline
\end{tabular}


Table 3 Electrolytic conductivity values in two purging scenarios

\begin{tabular}{lclllll}
\hline Piezometer & $2 \mathrm{v}_{\mathrm{d}}\left(\mathrm{dm}^{3}\right)$ & $\begin{array}{l}\mathrm{EC}(\mu \mathrm{S} / \mathrm{cm}) \\
\text { for } 2 \mathrm{v}_{\mathrm{d}}\end{array}$ & $3 \mathrm{v}^{*}\left(\mathrm{dm}^{3}\right)$ & $\begin{array}{l}\mathrm{EC}(\mu \mathrm{S} / \mathrm{cm}) \\
\text { for } 3 \mathrm{v}\end{array}$ & $\begin{array}{l}2 \mathrm{v}_{\mathrm{d}} / 3 \mathrm{v} \\
(-)\end{array}$ & $\mathrm{EC}_{2 \mathrm{vd}} / \mathrm{EC}_{3 \mathrm{v}}$ \\
\hline P1 & 17.3 & 1860 & 209.55 & 1574 & 12.11 & 1.18 \\
P2 & 161.47 & 1582 & 242.21 & 1579 & 1.50 & 1.00 \\
P9 & 170.98 & 1675 & 256.47 & 1817 & 1.50 & 0.92 \\
P10 & 170.97 & 3560 & 256.46 & 3630 & 1.50 & 0.99 \\
P17 & 3.925 & 902 & 5.89 & 841 & 1.50 & 1.07 \\
P17A & 7.85 & 6220 & 17.67 & 6750 & 2.25 & 0.92 \\
P19 & 7.85 & 1537 & 11.78 & 1587 & 1.50 & 0.97 \\
P19A & 7.85 & 1440 & 49.75 & 2330 & 6.34 & 0.62 \\
\hline
\end{tabular}

$2 \mathrm{v}_{\mathrm{d}}$-double volume of water column in the filtered zone of the piezometer

$3 \mathrm{v}$-triple volume of stagnant water in the piezometer

*According to 06.10 .2008 whether the previously observed regularities in EC variability during vertical profiling and purging are stable or variable. The relation between the EC changes and the chemical composition of the purged waters was also assessed. Four measuring series were undertaken (in the period 2012-2015) to assess the vertical variability of the EC within the stagnant water column in the P9 piezometer (Fig. 7). Comparative studies in the P10 piezometer were carried out four times (in the period 2014-2015) (Fig. 8). In all four series in P9, the lowest conductivity values were observed for measurements at depths of seven and nine meters below the orifice, i.e., just below the water table. The range of electrolytic conductivity changes at these depths was small, ranging from 252.1 to $408 \mu \mathrm{S} / \mathrm{cm}$ (Fig. 7).
In most cases for the P9 piezometer, the highest values of EC were obtained at the highest sampling depth, i.e., $15 \mathrm{~m}$ (up to $3310 \mu \mathrm{S} / \mathrm{cm}$ ). These values were around three to 10 times higher than the values measured at a depth of $7 \mathrm{~m}$. In the case of the P10 piezometer, significantly higher EC values were observed in the entire profile (from 1140 to $4169 \mu \mathrm{S} / \mathrm{cm}$ ) compared to the P9 piezometer (from 252.1 to $3310 \mu \mathrm{S} / \mathrm{cm}$ ). Further, in this case, the highest EC values were most often recorded at the bottom of the piezometer at a depth of $12 \mathrm{~m}$ and the lowest values were recorded at the depth of $5 \mathrm{~m}$ (Fig. 8). The highest EC values in the individual profiles in $\mathrm{P} 10$ were up to 2.5 times higher than the lowest values (Fig. 8); however, these differences were much smaller than in P9.
Fig. 7 Vertical changes of EC value in $\mathrm{P} 9$ piezometer before purging

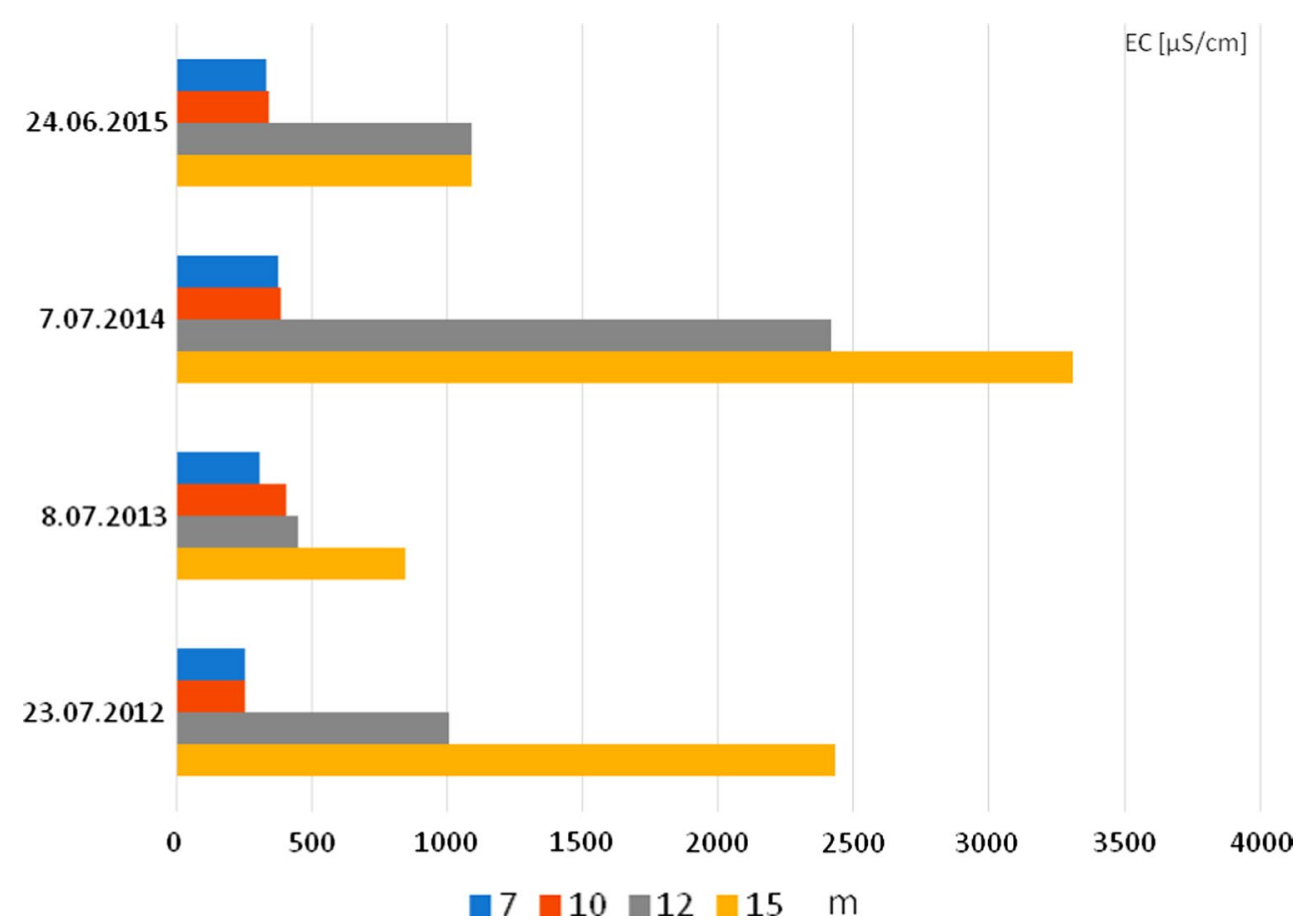


Fig. 8 Vertical changes of EC value in $\mathrm{P} 10$ piezometer before purging

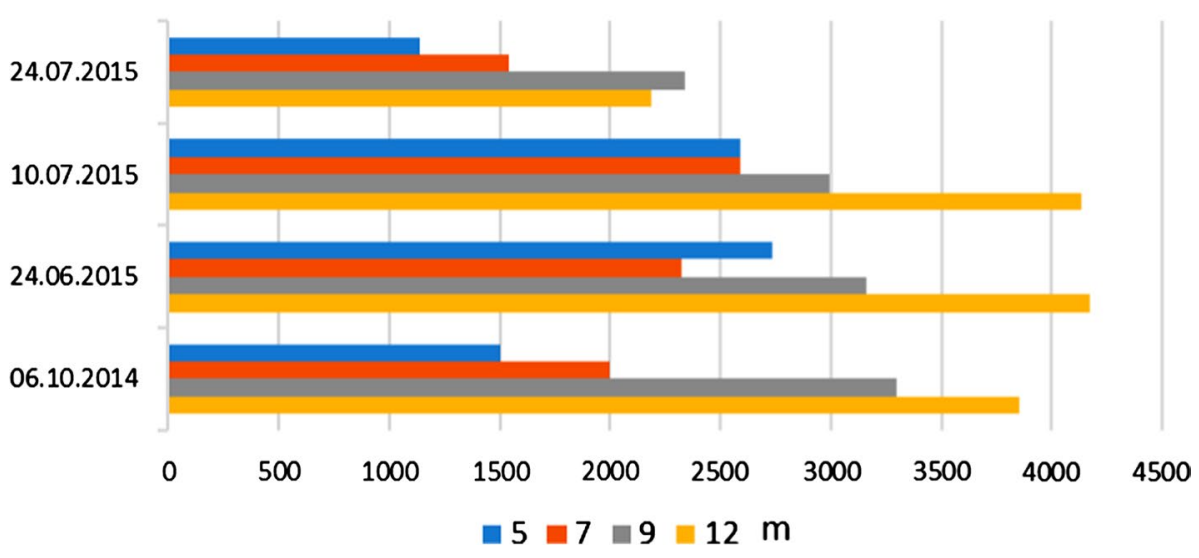

In the analyzed piezometer, $\mathrm{P} 9$ also in the second stage of research, the increasing trend in all of the measurement series was confirmed during the research purging (Fig. 9). After purging double the volume of water stagnating in the piezometer in any of the measurement series (as suggested), the value of this parameter was not stabilized. This testifies to the inflow of contaminated waters from the old landfill site. Large periodic EC changes to the tested waters testify to the variable impact of the inactive landfill on the waters captured in the $\mathrm{P} 9$ piezometer. This is due to both the variability of the load of pollutants generated by the landfill and the extent of the spatial contamination plume, as well as the diversity of the hydrodynamic system of the monitored aquifer. The observed fluctuations in the level of the groundwater table may cause changes to the direction of the groundwater flow in relation to the landfill (Fig. 4a, b). Increasing the water table elevation (Fig. 4a) may result in the increased inflow of less contaminated waters to the P9 piezometer (from the $\mathrm{W}$ and NW direction) and vice versalowering the water table elevation may cause a periodic higher inflow of more polluted waters (from the NE direction, i.e., from the landfill) (Fig. 4b). The relation between the depth of the groundwater table in piezometer P9 and the value of the electrolytic conductivity of the purged waters for the presented five measurement series is also visible in Fig. 9. Analysis of the results of the monitoring tests carried out in 1995-2015 (33 pairs of measurements) confirms the existence of a relationship between these data (Fig. 10).
Fig. 9 Changes to the EC value during purging of the $\mathrm{P} 9$ piezometer and removal of a successive number of well volumes in five measuring series

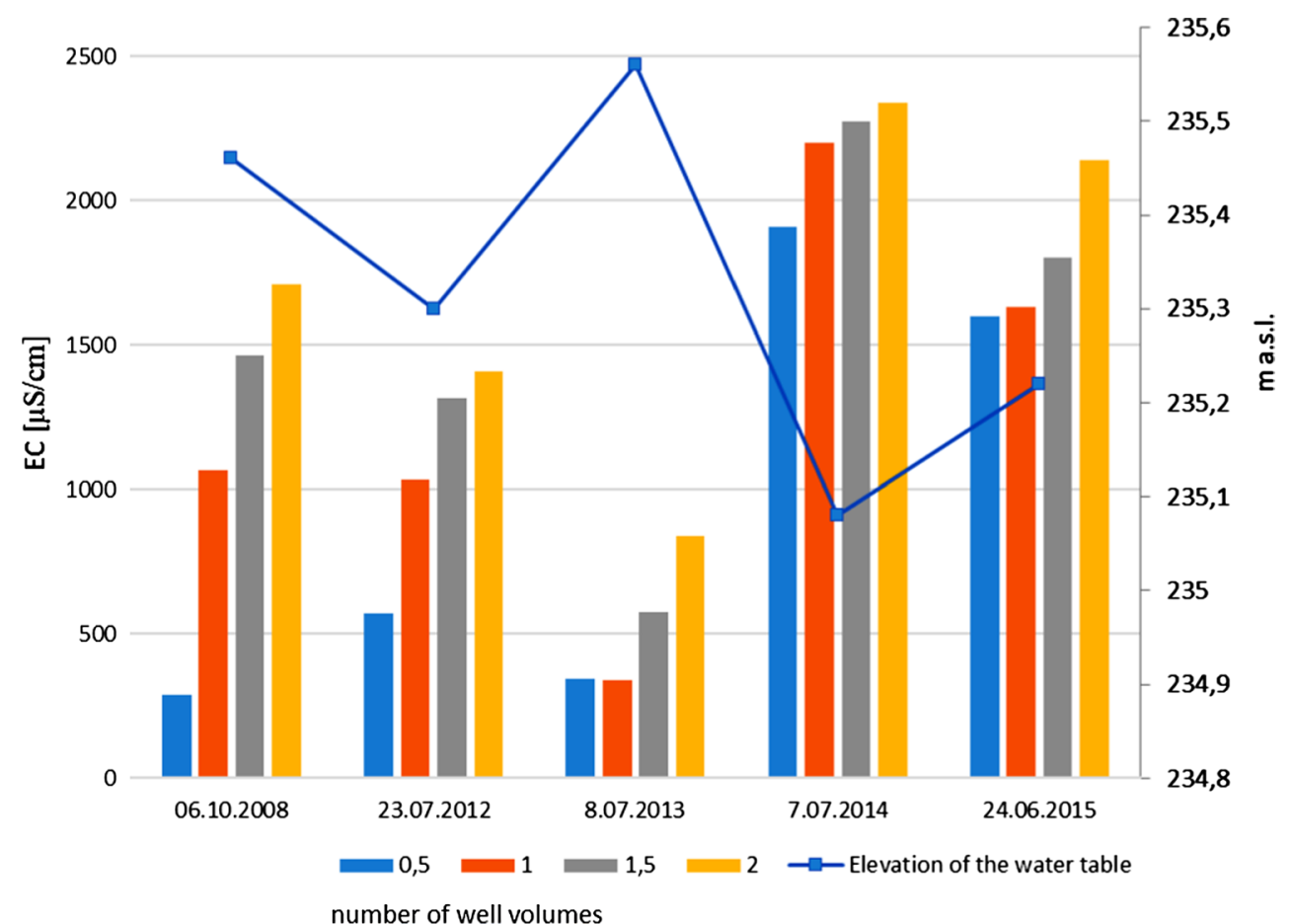




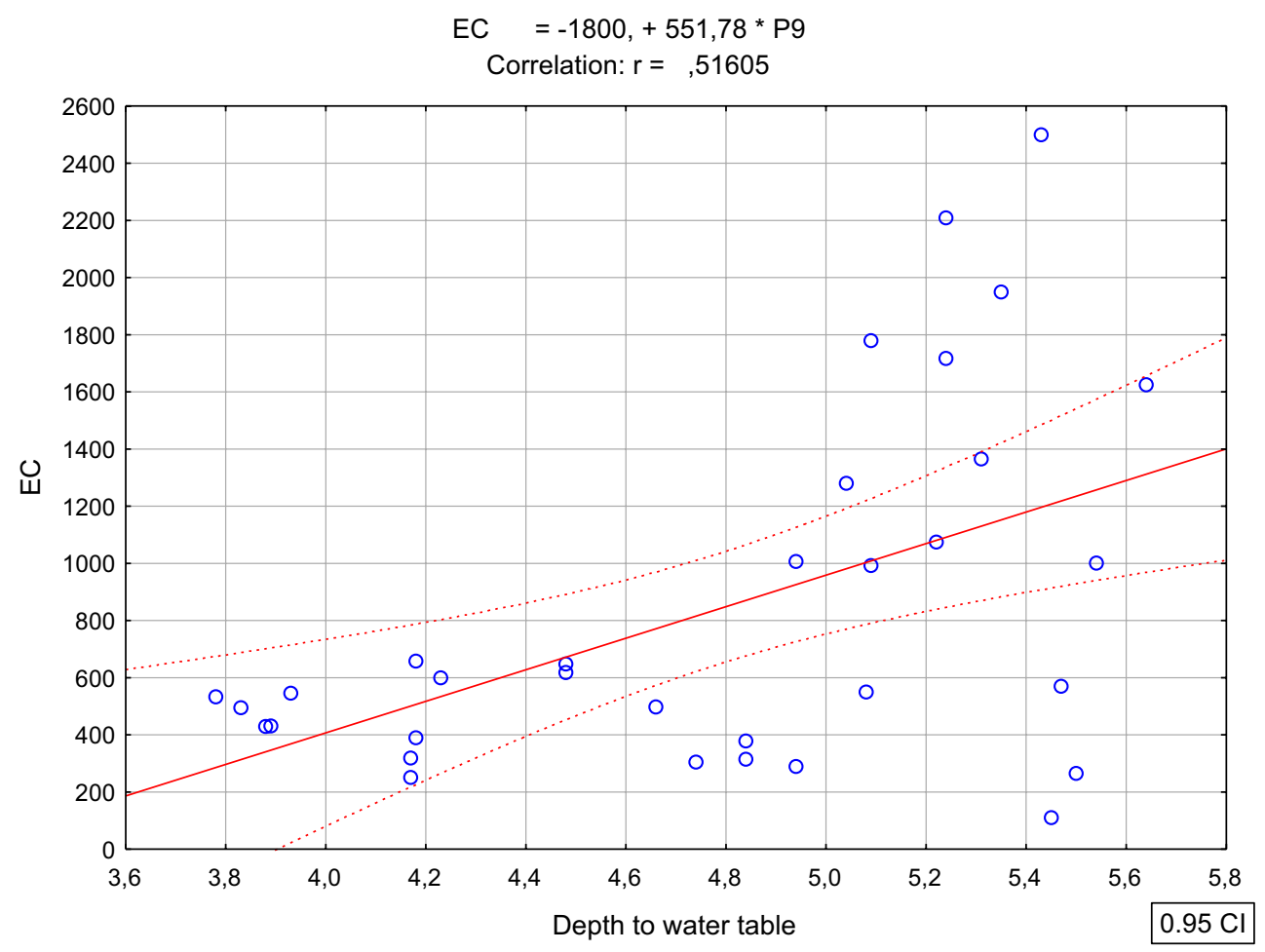

Fig. 10 Relationship between the depth to water table and the conductivity value in P9 piezometer

The obtained Pearson correlation coefficient at the level of approx. 0.52 indicates the average correlation between the considered depth for the groundwater table and the electrolytic conductivity (Fig. 10).

In the context of EC profiling with the use of a bailer, the question arises as to whether, and how, the vertical distribution influences the previously performed purging of the piezometer. With this in mind, the changes to the EC value in the $\mathrm{P} 9$ piezometer during vertical profiling, both before and after prolonged purging, were investigated [after purging 12 well volumes of stagnant water in the piezometer
(Fig. 11)]. Large changes to the EC size were found (from $252.1 \mu \mathrm{S} / \mathrm{cm}$ up to $2432 \mu \mathrm{S} / \mathrm{cm}$ ) prior to purging the piezometer and this trend increased with the depth of sampling. Following considerable purging and two hours of stabilization, the trend that increased with depth was no longer observed and the vertical variation was small (from 408 to $474 \mu \mathrm{S} /$ cm) (Fig. 11).

These data confirm the important role of the sampling methodology applied to obtain the results. The following data were obtained from samples taken from the $\mathrm{P} 9$ piezometer on the same day.
Fig. 11 Values of EC obtained from the vertical profiling of the $\mathrm{P} 9$ piezometer before and after purging

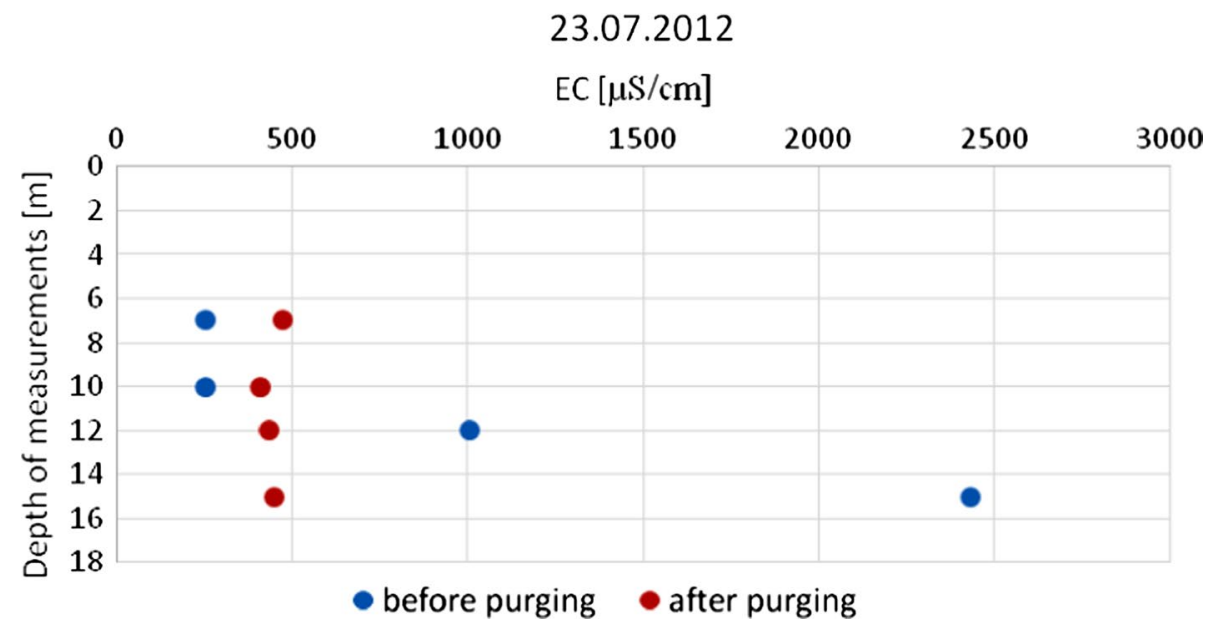


- Sampling with the bailer before purging:

$\min 25.1 \mu \mathrm{S} / \mathrm{cm}, \max 2432 \mu \mathrm{S} / \mathrm{cm}$, average $985.83 \mu \mathrm{S} /$ $\mathrm{cm}$.

- Sampling with the bailer after prolonged purging: $\min 408 \mu \mathrm{S} / \mathrm{cm}, \max 474 \mu \mathrm{S} / \mathrm{cm}$, average $440.75 \mu \mathrm{S} / \mathrm{cm}$.

- Pumping and after the removal of two volumes of stagnant water:

$\min 569.5 \mu \mathrm{S} / \mathrm{cm}$ (after purging about 0.5 volume of stagnant water), max $1410 \mu \mathrm{S} / \mathrm{cm}$ (after removing two volumes of stagnant water), average during purging, $1082.37 \mu \mathrm{S} / \mathrm{cm}$.

The analysis only takes into account the variability of the EC as a comprehensive indicator of contamination. The issue of how EC values affect changes in the chemical composition of groundwater during purging is quite important. For this purpose, in 2015, the chemical composition of the groundwater purged out of piezometers P9 and P10 was determined. The chemical composition of the stagnant water and four consecutive well volumes in the piezometers were determined. A sample of stagnant water, designated as "volume 0 ," was taken from the first liter of water purged out of the piezometer.

In the case of the $\mathrm{P} 10$ piezometer, no significant changes in the value of the individual parameters were noticed during purging (Fig. 12, Table 4). The EC measurements indicate stability (changes in the minimum range: $3841-3946 \mu \mathrm{S} /$ $\mathrm{cm})$. Similar behavior was demonstrated in a number of the examined indicators, e.g., $\mathrm{Mg}, \mathrm{Na}, \mathrm{Ca}, \mathrm{B}, \mathrm{Cl}, \mathrm{SO}_{4}, \mathrm{Ni}, \mathrm{NO}_{3}$. The maximum values of the tested parameters were most often observed in stagnant water ("volume 0") $\left(\mathrm{EC}, \mathrm{NH}_{4}\right.$, $\mathrm{Mg}, \mathrm{K}, \mathrm{Fe}, \mathrm{B}, \mathrm{HCO}_{3}, \mathrm{SO}_{4}$, TOC in Table 4). Maximum concentrations were found in $\mathrm{Mn}, \mathrm{Na}, \mathrm{Cl}$ and $\mathrm{SO}_{4}$. During purging, a slight increase in the content of $\mathrm{Mn}, \mathrm{Na}, \mathrm{Ca}, \mathrm{Cl}$ and $\mathrm{SO}_{4}$, as well as a decrease in $\mathrm{EC}$ and $\mathrm{HCO}_{3}, \mathrm{~K}, \mathrm{TOC}$ and $\mathrm{B}$ content was found. The EC of the studied waters was mainly determined by the increased content of pollution indices, such as $\mathrm{HCO}_{3}, \mathrm{Cl}, \mathrm{Na}, \mathrm{Ca}, \mathrm{K}, \mathrm{Mg}$ and $\mathrm{NH}_{4}$, and, to a lesser extent, $\mathrm{SO}_{4}$.

Accepting the results of the chemical analyzes as representative, even for the water stagnant from the P10 piezometer, would not have the same significance as it would in the case of the other piezometers, which are subject to the changing influence of the landfill. For the P10 piezometer, the greatest variations between the values in the stagnant water and in individual well volumes were obtained for manganese, potassium, ammonium ion and chlorides. In the case of manganese, the content found in the stagnant water was $45 \%$ lower than that in three well volumes. For the other three components, the differences did not exceed $19 \%$. With a $1.9 \%$ variation between the EC value for stagnant water and water after purging two well volumes, it can be said that these waters are subject to a constant negative impact of the landfill and their quality is poor, regardless of the methodology used for monitoring. The low chemical state of these waters was determined by both the minimum and maximum $\mathrm{EC}$ values, as well as the $\mathrm{NH}_{4}, \mathrm{Mg}, \mathrm{Mn}, \mathrm{Ni}, \mathrm{K}, \mathrm{Na}, \mathrm{Fe}, \mathrm{B}$, $\mathrm{HCO}_{3}, \mathrm{Cl}$ and TOC concentrations obtained at each purging stage (Table 4). However, this conclusion cannot be reached

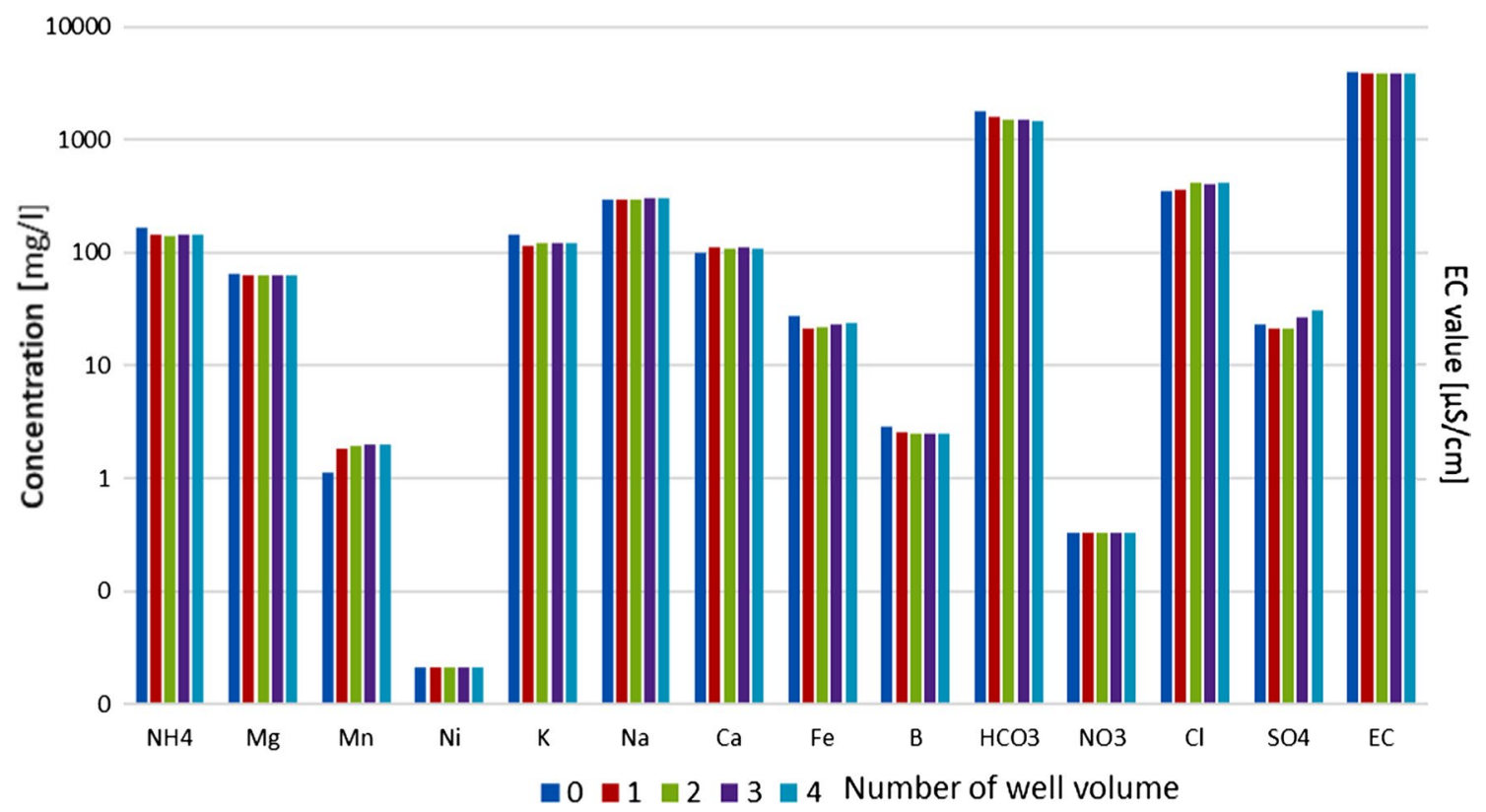

Fig. 12 Changes of the values of pollution indices during purging of P10 piezometer and removal of a successive number of well volumes 
Table 4 Changes to pollution indices before and during purging and removal of a successive number of well volumes in P9 and P10 piezometers

\begin{tabular}{|c|c|c|c|c|c|c|}
\hline & & & & Jumber of & vell volum & \\
\hline Parameter & Piezometer & Purging beginning & 1 & 2 & 3 & 4 \\
\hline $\mathrm{EC}(\mu \mathrm{S} / \mathrm{cm})$ & P9 & 1630 & 2141 & 2319 & 2465 & 2531 \\
\hline & $\mathrm{P} 10$ & 3946 & 3882 & 3886 & 3874 & 3841 \\
\hline $\mathrm{NH}_{4}(\mathrm{mg} / \mathrm{l})$ & P9 & 65 & 71 & 80 & 84 & 87 \\
\hline & P10 & 167 & 144 & 141 & 143 & 143 \\
\hline $\mathrm{Mg}(\mathrm{mg} / \mathrm{l})$ & P9 & 32 & 39 & 43 & 45 & 48 \\
\hline & $\mathrm{P} 10$ & 64 & 63 & 63 & 63 & 63 \\
\hline $\mathrm{Mn}(\mathrm{mg} / \mathrm{l})$ & P9 & 1.7 & 2.4 & 2.7 & 2.7 & 2.9 \\
\hline & $\mathrm{P} 10$ & 1.1 & 1.8 & 1.9 & 2.0 & 2.0 \\
\hline $\mathrm{Ni}(\mathrm{mg} / \mathrm{l})$ & P9 & 0.029 & 0.035 & 0.035 & 0.038 & 0.035 \\
\hline & P10 & 0.021 & 0.021 & 0.021 & 0.021 & 0.021 \\
\hline $\mathrm{K}(\mathrm{mg} / \mathrm{l})$ & P9 & 52 & 70 & 78 & 83 & 89 \\
\hline & $\mathrm{P} 10$ & 145 & 116 & 120 & 122 & 120 \\
\hline $\mathrm{Na}(\mathrm{mg} / \mathrm{l})$ & P9 & 98 & 135 & 152 & 159 & 165 \\
\hline & P10 & 296 & 292 & 290 & 299 & 299 \\
\hline $\mathrm{Ca}(\mathrm{mg} / \mathrm{l})$ & P9 & 60 & 63 & 68 & 70 & 74 \\
\hline & $\mathrm{P} 10$ & 101 & 112 & 109 & 110 & 108 \\
\hline $\mathrm{Fe}(\mathrm{mg} / \mathrm{l})$ & P9 & 0.052 & 0.032 & 0.047 & 0.055 & 0.067 \\
\hline & $\mathrm{P} 10$ & 28 & 21 & 22 & 23 & 24 \\
\hline $\mathrm{B}(\mathrm{mg} / \mathrm{l})$ & P9 & 0.80 & 1.2 & 1.4 & 1.5 & 1.6 \\
\hline & $\mathrm{P} 10$ & 2.9 & 2.6 & 2.5 & 2.5 & 2.5 \\
\hline $\mathrm{HCO}_{3}(\mathrm{mg} / \mathrm{l})$ & $\mathrm{P9}$ & 543 & 687 & 736 & 813 & 865 \\
\hline & $\mathrm{P} 10$ & 1764 & 1569 & 1509 & 1485 & 1468 \\
\hline $\mathrm{NO}_{3}(\mathrm{mg} / \mathrm{l})$ & P9 & 10 & 0.4450 & 1.7 & 2.0 & 1.4 \\
\hline & P10 & 0.33 & 0.33 & 0.33 & 0.33 & 0.33 \\
\hline $\mathrm{Cl}(\mathrm{mg} / \mathrm{l})$ & P9 & 162 & 224 & 248 & 252 & 260 \\
\hline & $\mathrm{P} 10$ & 350 & 360 & 410 & 400 & 410 \\
\hline $\mathrm{SO}_{4}(\mathrm{mg} / \mathrm{l})$ & P9 & 92 & 73 & 87 & 81 & 72 \\
\hline & P10 & 23 & 21 & 21 & 27 & 31 \\
\hline TOC (mg/l) & P9 & 36 & 31 & 34 & 35 & 37 \\
\hline & $\mathrm{P} 10$ & 52 & 48 & 49 & 49 & 47 \\
\hline $\mathrm{Cu}(\mathrm{mg} / \mathrm{l})$ & P9 & 0.0070 & 0.012 & 0.012 & 0.011 & 0.012 \\
\hline & $\mathrm{P} 10$ & $<0.004$ & $<0.004$ & $<0.004$ & $<0.004$ & $<0.004$ \\
\hline $\mathrm{Zn}(\mathrm{mg} / \mathrm{l})$ & P9 & 0.00250 & 0.00250 & 0.00250 & 0.00250 & 0.00250 \\
\hline & $\mathrm{P} 10$ & 0.0050 & 0.0060 & 0.0070 & 0.0060 & $<0.005$ \\
\hline $\mathrm{PO}_{4}(\mathrm{mg} / \mathrm{l})$ & P9 & 0.02500 & 0.02500 & 0.02500 & 0.02500 & 0.02500 \\
\hline & $\mathrm{P} 10$ & $<0.050$ & $<0.050$ & $<0.050$ & $<0.050$ & $<0.050$ \\
\hline $\mathrm{Cd}(\mathrm{mg} / \mathrm{l})$ & P9 & 0.0001 & 0.0001 & 0.0001 & 0.0001 & 0.0001 \\
\hline & P10 & 0.0010 & 0.0011 & 0.0012 & 0.00090 & 0.00050 \\
\hline
\end{tabular}

unpolluted

slightly polluted

moderately polluted

good chemical status

heavily polluted

very heavily polluted

poor chemical status 
with the P9 piezometer (Fig. 13) in which, with the exception of the content of nickel, nitrates and sulfates, an increasing trend for all physicochemical parameters was observed.

In the case of piezometer $\mathrm{P} 9$, there were significant differences in the values of the individual parameters between stagnant water and the other results. The EC value in stagnant water was $33 \%$ lower than in the three well volumes. Quite large differences were also observed in boron-88\%, sodium-62\%, manganese-59\%, chlorides-56\% and bicarbonates- $49 \%$. The variability of the content of nitrogen compounds is also noteworthy. The nitrate content was four times higher in stagnant water than in the three well volume. The content of ammonium ion dropped by almost $30 \%$. The low chemical state of the water in this piezometer was determined by both the minimum and maximum concentrations of $\mathrm{NH}_{4}, \mathrm{Na}$ and TOC obtained at each stage of purging (Table 4). In turn, due to the boron content, the stagnant water was in a good chemical state and, in the later stages of purging, was in a poor condition. Due to the content of chlorides, the water sampled in the first three stages of purging was in a good chemical state and in the next two stages the condition was poor (Table 4).

\section{Discussion}

The comprehensive research carried out for the observation network of the municipal waste landfill in Tychy facilitated the assessment of the impact of the above-mentioned conditions on the reliability and representativeness of the results of the monitoring tests. During the two-stage tests, differentiated research purging and vertical profiling were performed in eight selected piezometers (P1, P2, P9, P10, P17, P17A, P19, P19A) with simultaneous measurement of the electrolytic conductivity value. As part of the second stage, in two selected piezometers (P9 and P10), an extended scope of research was carried out that, in addition to the aforementioned multivariate EC measurements, included an analysis of the chemical composition of the tested groundwater.

Different results were obtained using different testing technology for the same piezometers. This is perfectly visible in the example of EC variability (Table 5). In the vast majority of piezometers (with the exception of P19A), vertical profiling using a bailer indicated a marked increase in the EC value with depth.

As observed in the stagnant water in piezometers, the vertical variability of the EC may be the result of the overlap of a number of factors: the location of the piezometers in relation to the landfill and the spatial extent of contamination plume (longitudinal and transversal dispersion), the density fractionation (mainly in nested piezometers with short filters

$\square 0=1=2 \square 3 \square 4 \quad$ Number of well volume

10000

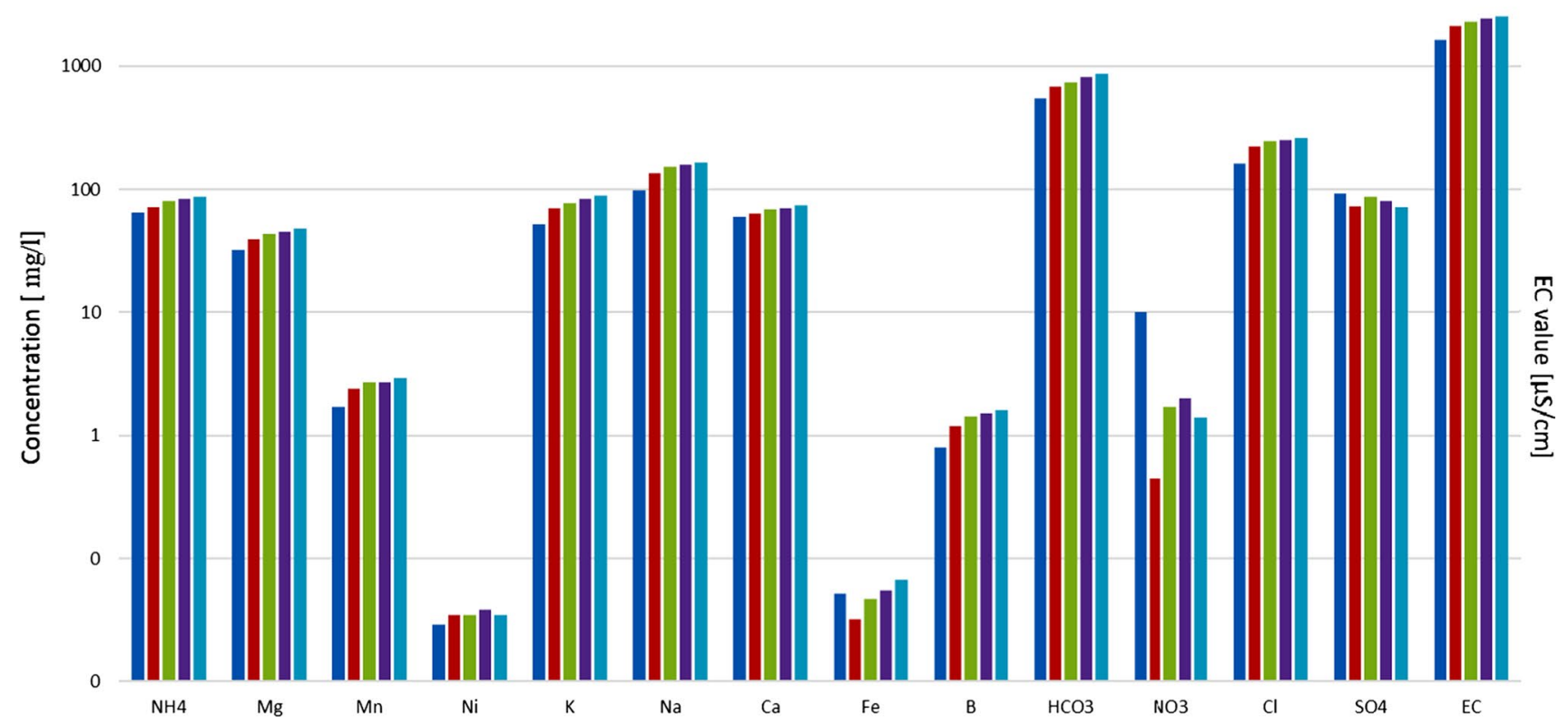

Fig. 13 Changes of the values of pollution indices during purging of $\mathrm{P} 9$ piezometer and removal of a successive number of well volumes 
Table 5 Summary results of EC values obtained using different sampling technology (data from 2008)

\begin{tabular}{|c|c|c|c|c|c|c|}
\hline \multirow[t]{2}{*}{ Piezometer } & \multicolumn{2}{|c|}{$\begin{array}{l}\mathrm{EC}(\mu \mathrm{S} / \mathrm{cm}) \text { value from vertical } \\
\text { profiling }\end{array}$} & \multicolumn{4}{|c|}{$\begin{array}{l}\mathrm{EC}(\mu \mathrm{S} / \mathrm{cm}) \text { value from purging/number of wel } \\
\text { volume }\end{array}$} \\
\hline & $\begin{array}{l}\text { Upper part of } \\
\text { aquifer }\end{array}$ & $\begin{array}{l}\text { Lower part of } \\
\text { aquifer }\end{array}$ & 1 & 2 & 3 & 4 \\
\hline P1 & 1355 & 1848 & 2100 & 1807 & 1574 & 1469 \\
\hline P2 & 501 & 2210 & 1700 & 1612 & 1579 & 1550 \\
\hline P9 & 311 & 2130 & 1068 & 1643 & 1817 & 1888 \\
\hline P10 & 1778 & 4420 & 3270 & 3500 & 3630 & 3800 \\
\hline P17 & 601 & 1140 & 888 & 861 & 841 & 831 \\
\hline P17A & 1320 & 7570 & 6770 & 6760 & 6750 & 6710 \\
\hline P19 & 1240 & 1450 & 1496 & 1574 & 1587 & 1587 \\
\hline P19A & 1049 & 957 & 1712 & 2100 & 2330 & 2480 \\
\hline
\end{tabular}

with a much longer water column-P17, P17A, P19, P19A), vertical flows (mainly in piezometers with long filters that cover the entire thickness of the aquifer-P1, P2, P9, P10) and more intensive water exchange in the filtration zones of rocks with increased permeability (e.g., gravel in P1, P2 and P9 or coarse sands in P19A) (Table 1). The construction of the piezometers may also have a significant influence (e.g., the existence of two filter sections in piezometers P1 and P9). It should also be noted that the observed vertical variations might result from the possibility of having diluted the sample while removing the bailer from the borehole.

Different results were obtained from sampling piezometers while removing various volumes of stagnant water using a submersible pump. These variations are much smaller than when using a sampler (Table 5). However, in some cases (e.g., P1, P9 and P19A) they are sufficiently significant to influence the assessment of the status of the water quality. It is interesting to note that both increases (P9, P10, P19 and P19A) and decreases (in P1 and P2) were observed during purging, as well as the practical stabilization (minimal practical decreases within the error limits of the measurements in P17 and P17A) of the EC values of the waters studied (Table 5). The increase is recorded in piezometers close to the landfill and its zone of permanent (P10, P19 and P19A) or periodic negative impact (P9). In these regions, heavily contaminated waters in the lower parts of the aquifer migrate upwards and are diluted by infiltrating rainwater. Purging the piezometer removes, first, the less mineralized water from the upper part of the aquifer and, second, the more mineralized water from the lower part. Piezometers P1 and P2, which are located to the east from the landfill in the area of the marginal influence of the inactive landfill site, behave differently. During their purging, small reductions in EC value were noted. Water from both piezometers can be supplied by both the closed landfill (contaminated) and the active landfill (uncontaminated) sites. The dominant component of the inflow of waters from the NE direction may cause a decrease in water mineralization (Fig. 4). In turn, the relative stability of EC values is observed in piezometers P17 and P17A, which are situated further away from the landfill site in the water outflow zone and in the central part of the contamination plume.

As already mentioned, depending on the applied sampling methodology, relatively large differences in EC values may contribute to a varied assessment of the range and degree of the negative impact of the monitored facility on the quality of groundwater (Fig. 14).

Taking into account the results of the vertical EC profiling in the zone located directly under the water table, the assessment of the impact of the landfill on groundwater is highly optimistic, indicating a small range of the contamination plume (Fig. 14a). The EC values obtained from the piezometers before purging at low depths are very low and do not exceed $1500 \mu \mathrm{S} / \mathrm{cm}$. A significantly larger impact of the landfill can be identified by taking account of the results obtained from the vertical profiling from the bottom part of the borehole log (Fig. 14b). In this case, the range of the plume in the southerly direction is much larger and the extreme EC values exceed $7500 \mu \mathrm{S} / \mathrm{cm}$ (P17A).

A similar situation occurs when taking account of the results obtained during purging. In this case, the range of the contamination plume was determined separately for either one or three well volumes purged from the piezometer in two scenarios: (1) noting only the results from piezometers (P17 and P19) that capture the upper part of the aquifer (Fig. 14c, e) and (2) only those from piezometers (P17A and P19A) that capture the lower part of the aquifer (Fig. 14d, f). Comparison of the solute plume range in the four variants (Fig. 14c-f) shows that the depth of the tested piezometers plays a dominating role. A significant difference is seen in the interpreted plume range for the upper and lower parts of the aquifer, regardless of the number of well volumes pumped out (Fig. 14c-f). However, the difference between the reach of the landfill impact after purging one or three well volumes in both the upper part of the aquifer (Fig. 14c, e) and the lower part (Fig. 14d, f) is already small. 
Fig. 14 Isocontours of electric conductivity (EC) with a different sampling technology (EC in $\mu \mathrm{S} / \mathrm{cm})$

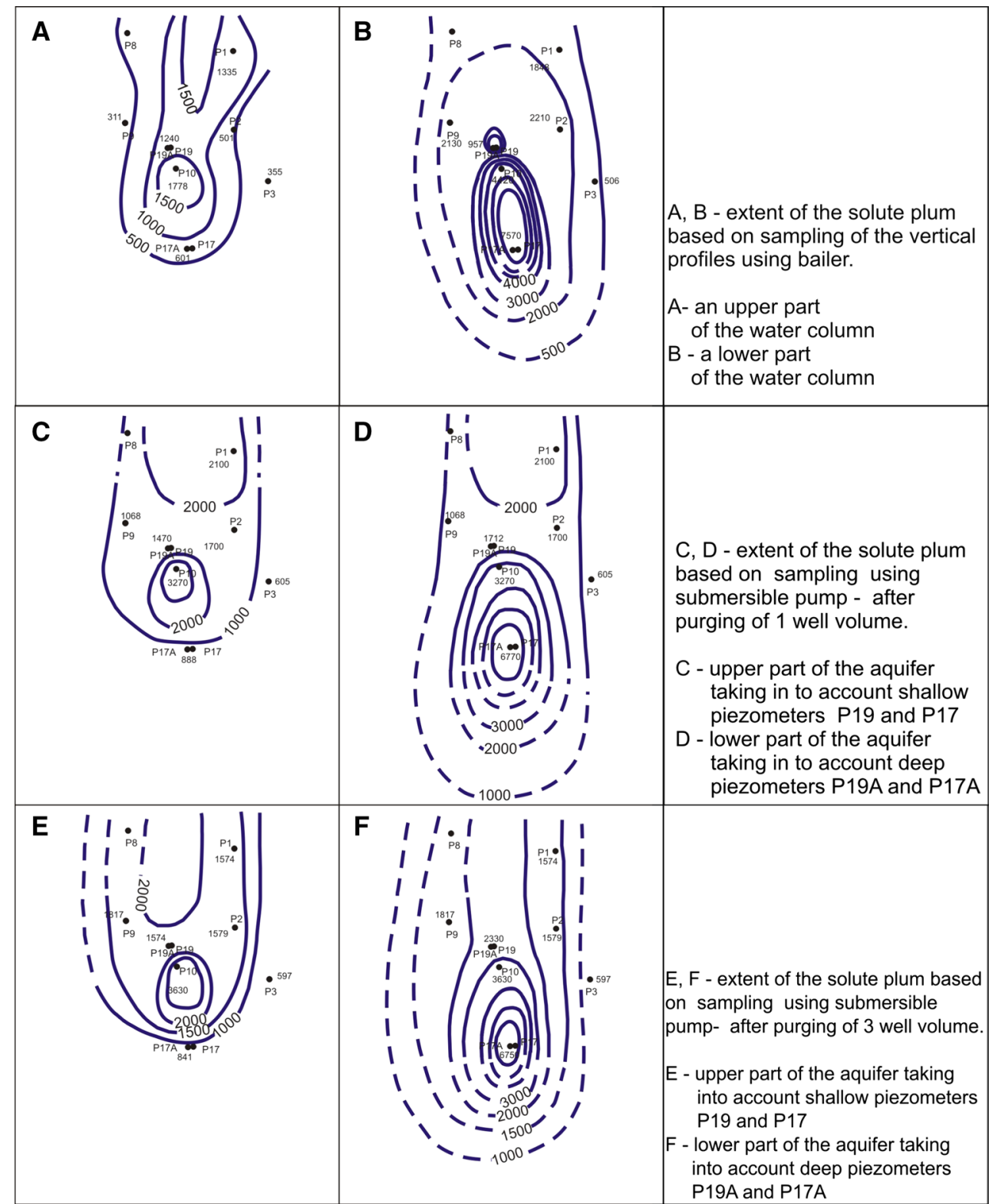

A further factor raised in this article is the issue of limiting the amount of water pumped out of the piezometers. Rather than using the two-three suggested multiples volumes of stagnant water in the piezometer ( 2 or $3 \mathrm{v}$ ), a double volume of water column in the filtered zone of the piezometer $\left(2 v_{d}\right)$ could be purged. This solution would be beneficial (in terms of time and finances) for companies monitoring the quality of groundwater around landfills. The results of calculations carried out in the area of the landfill in Tychy indicate that purging limited volumes of water could be used for piezometers for which the ratio of $3 v$ to $2 v_{d}$ is 1.5 or less (Table 3). Significantly higher values of this ratio, obtained for piezometers P1, P19A and P17A (Table 3), indicate quite significant differences in $\mathrm{EC}$ values, which call into question the possibility of using this method for piezometers with short sections of filter that capture a large thickness of the aquifer.

Analyzing the representativeness of the results of the monitoring of groundwater quality in the context of the applied sampling methodology, attention was also paid to the impact of long-term purging on the value and vertical variability of the EC. The tests performed in 2012 in the P9 piezometer, consisting of vertical profiling before purging and after prolonged purging, indicate very large differences in both the EC values and in their vertical distribution (Fig. 11). Before purging, the vertical variation of the EC value was large, amounting to $2.180 \mu \mathrm{S} / \mathrm{cm}$ (from 252 to $2432 \mu \mathrm{S} / \mathrm{cm}$ ), and following purging it was only $66 \mu \mathrm{S} /$ $\mathrm{cm}$ (from 408 to $474 \mu \mathrm{S} / \mathrm{cm}$ ). The large variation between the pre-purging EC values may be related to the fact that 
stagnant water in the unpurged piezometer has been there for a long time (over 2 weeks) and referred to the horizontal range and vertical gradient of the contamination plume. In this case, the average EC value from vertical profiling was $985.85 \mu \mathrm{S} / \mathrm{cm}$. However, the water sampled after purging the piezometer was fresh water, representing the current, momentary hydrodynamic state and having EC average values that are more than $50 \%$ lower than those found prior to purging (average of $440.75 \mu \mathrm{S} / \mathrm{cm}$ ).

Based on data of the EC values obtained from vertical profiling and after purging different multiples of stagnating water in the piezometers, the assessment of the impact of the pollution source (the old municipal landfill) on the groundwater can produce completely divergent results. Such conclusions result not only from analyzes of the EC values but also from the results of chemical analyzes of selected physicochemical parameters (Table 4).

\section{Conclusions}

In recent decades, much attention has been devoted to the development of uniform laboratory methods for the analysis of water samples, but, unfortunately, little has been done to develop uniform sampling methods. This has resulted in the creation of sometimes pointless data and a significant loss of time and financial outlay. In this context, this article fits in with the still valid subject of the reliability and representativeness of the results of groundwater monitoring studies.

The goal of the study was to report the impact of a groundwater monitoring methodology for the assessment of the pollution sources of groundwater quality in the region of landfills. Obtained results indicate that sampling method should be adapted to the location of the piezometer relative to the pollution source. Using only vertical profiling can generate very optimistic results. In the measuring series from 2008, pumped out from four well volumes up to nine well volumes before the stabilization of EC value was achieved. Therefore, it is not unambiguous to assume that purging of two volumes of water is sufficient.

Conducting a representative monitoring of groundwater quality in the area of pollution sources requires the use of a specific methodology to perform sampling for analysis. The research results presented in this article confirm the very large differences in data that occur as a consequence of the sampling technology, the depth of sampling, the piezometer construction and its lithological profile, as well as the duration and intensity of the research.

A reliable interpretation of the obtained test results should take into account the representativeness of the measurement points, their location relative to the pollution center and within the current hydrodynamic system, the inhomogeneity of the aquifer system and the piezometer construction (e.g., depth, filtration intervals). The representativeness of the monitoring data has a significant effect on the reliable assessment of the impact of pollution sources on the chemical status of groundwater and on the determination of the real spatial extent of the contamination plume.

In order to determine the real-time variability and spatial diversity of the contamination of monitored waters, the tests should always be carried out in the same way and according to a fixed schedule.

Open Access This article is distributed under the terms of the Creative Commons Attribution 4.0 International License (http://creativeco mmons.org/licenses/by/4.0/), which permits unrestricted use, distribution, and reproduction in any medium, provided you give appropriate credit to the original author(s) and the source, provide a link to the Creative Commons license, and indicate if changes were made.

\section{References}

Barcelona M, Helfrich J (1986) Well construction and purging effects on ground-water samples. Environ Sci Technol 20(11):1179-1184

Barcelona M, Wehrraann H, Varljen M (1994) Repro-ducible well purging procedures and VOC stabilization criteria for ground water sampling. Ground Water 32(1):12-22

Broers HP (2004) The spatial distributions of groundwater age for different geohydrological situations in the Netherlands: implications for groundwater quality monitoring at the regional scale. J Hydrol 299:57-72

Church PE, Granato GE (1996) Bias in groundwater data caused by well-bore flow in long-screen wells. Ground Water 34:262-273

Czermiński P (1993) User manual of the groundwater monitoring network in the region of the municipal landfill in Tychy- Urbanowice (in Polish with English summary). EKO-SON, Tychy

Dąbrowska D (2012) Variation in the chemical composition of groundwater in the region of the inactive landfill in Tychy-Urbanowice (in Polish with English summary). MSc thesis, Sosnowiec

Dąbrowska D, Sołtysiak M, Witkowski A (2015) The influence of the number of boreholes and the interpolation method for the contouring map precision (in Polish with English summary). Przegląd Geologiczny 63(1):661-665

Dąbrowska D, Kucharski R, Witkowski A (2016) The representativity index of a simple monitoring network with regular theoretical shapes and its practical application for the existing groundwater monitoring network of the Tychy-Urbanowice landfills, Poland. Environ Earth Sci 75:749

Elci A, Flach GP, Molz EJ (2003) Detrimental effects of natural vertical head gradients on chemical and water level measurements in observation wells: identification and control. J Hydrol 281:70-81

EPA (1991) Handbook groundwater. EPA/625/6-90/016b. Volume II: methodology. U.S. Environmental Protection Agency, Centre for Environmental Research Information, Cincinati

Gibs J, Szabo Z, Ivahnenko T, Wilde F (2000) Change in field turbidity and trace element concentrations during well purging. Ground Water 38(4):577-588

Gomo M, Vermeulen D, Lourens P (2017) Groundwater sampling: flow-through bailer passive method versus conventional purge method. Nat Resour Res. https://doi.org/10.1007/s1105 3-017-9332-937

Grath J, Scheidleder A, Uhlig S, Weber K, Kralik M, Keimel T, Gruber D (2001) The EU water framework directive: statistical aspects of the identification of groundwater pollution trends and aggregation 
of monitoring results. Final report. Austrian Federal Ministry of Agriculture and Forestry, Environment and Water Management

Harte P (2017) In-well time-of-travel approach to evaluate optimal purge duration during low-flow sampling of monitoring wells. Environ Earth Sci. https://doi.org/10.1007/s12665-017-6561-5

Herzog B, Pennio J, Nielsen G (1991) Ground-Water Sampling. In: Nielsen DM (ed) Practical Handbook of Ground-Water Monitoring. Lewis Publishers Inc., Chelsea, Michigan

Hosseini M, Kerachian R (2017) A data fusion-based methodology for optimal redesign of groundwater monitoring networks. J Hydrol 552:267-282

Jousma G, Roelofsen FJ (2004) World-wide inventory on groundwater monitoring. Report nr. GP 2004-1. IGRAC, Utrecht

Lasagna M, De Luca A (2016) The use of multilevel sampling techniques for determining shallow aquifer nitrate profiles. Environ Sci Pollut Res 23(20):20431-20448

MacFarlane D, Cherry J, Gillham J, Sudicky E (1983) Migration of contaminants in groundwater at a landfill: a case study: 1 . Groundwater flow and plume delineation. J Hydrol 63(1-2):1-29

Martin-Hayden M (2000) Controlled laboratory investigations of wellbore concentration response to pumping. Ground Water 38(1):121-128

McMillan L, Rivett M, Tellam J, Dumble P, Sharp H (2014) Influence of vertical flows in wells on groundwater sampling. J Contam Hydrol 169:50-61

Mor S, Ravindra K, Dahiya R, Chandra A (2006) Leachate characterization and assessment of groundwater pollution near municipal solid waste landfill site. Environ Monit Assess 118(1):435-456

Nielsen DM (1992) Current practices in ground water and vadose zone investigations. ASTM International, West Conshohocken, p 431

Nielsen DM (ed) (2006) Practical handbook of environmental site characterization and ground-water monitoring, 2nd edn. CRC Press Taylor \&Francis Group, Boca Raton, p 1318

Nielsen DM, Nielsen G (2006) The essential handbook of ground-water sampling. CRC Press, Boca Raton, p 328

Nunes L, Cunha M, Ribeiro L (2004) Optimal space-time coverage and exploration costs in groundwater monitoring networks. Environ Monit Assess 93(1):103-124

Pohlmann KF, Icopini GA, McArthur RD, Rosal CD (1984) Evaluation of sampling and field-filtration methods for the analysis of trace metals in ground water. EPA/600/SR-94/119. United States Environmental Agency. Las Vegas, NV 89193-3478

Popek E (2003) Sampling and analysis of environmental chemical pollutants: a complete guide. Academic Press, Cambridge, p 356

Powell RM, Puls RW (1993) Passive sampling of groundwater monitoring wells without purging: multilevel well chemistry and tracer disappearance. J Contam Hydrol 12:51-77

Puls RW, Paul CJ (1995) Low-flow purging and sampling of ground water monitoring wells with dedicated systems. Ground Water Monit Rem 15(1):116-123

Qi S, Hou D, Luo J (2017) Optimization of groundwater sampling approach under various hydrogeological conditions using a numerical simulation model. J Hydrol 552:505-515
Quevauviller P, Fouillac AM, Grath J, Ward R (2009) Groundwater monitoring. Water quality measurements series. Willey, New York, $\mathrm{p} 428$

Robin MJL, Gillham R (1987) Field evaluation of well purging procedures. Ground Water Monit Rev 7(4):85-93

Sevee J, White C, Maher D (2000) An analysis of low-flow ground water sampling methodology. Groundw Monit Rem 20(2):87-93

Sitek S, Witkowski A, Kowalczyk A, Żurek-Pucek A (2010) Impact assessment of municipal landfill in Tychy on groundwater environment-modelling study (in Polish with English summary). Biuletyn Państwowego Instytutu Geologicznego 442:147-152

Trybuła B, Zając A (2011) Groundwater quality monitoring for the municipal landfill in Tychy-Urbanowice (in Polish). SGS EKO PROJEKT Ltd., unpublished

U.S. Office of Surface Mining Reclamation and Enforcement (2012) Well purging procedures for obtaining valid water samples from domestic and monitoring wells

Van Geer FC, Bierkens M, Broers H (2008) Groundwater monitoring strategies. Encycl Hydrol Sci. https://doi.org/10.1002/04708 48944.hsa316

Witczak S, Kania J, Kmiecik E (2013) Catalogue of the selected physical and chemical indicators of groundwater contamination and methods of their determination (in Polish). The Library of the Environmental Monitoring, Warsaw

Witkowski AJ (2006) Assessing causes of groundwater pollution of Quaternary aquifer in the area of the inactive landfill site in TychyUrbanowice (in Polish). Intergeo Limited Company, Sosnowiec

Witkowski AJ (2008) Groundwater quality monitoring for the postexploitation phase of the municipal landfill site in Tychy- Urbanowice (in Polish). Archive of Intergeo Ltd., unpublished

Witkowski AJ (2009) Remarks on groundwater monitoring for communal landfills (in Polish with English summary). Bull Pol Geol Inst 436:535-546

Witkowski AJ (2015) Groundwater quality monitoring in the afterclosure phase of the municipal landfill in Tychy-Urbanowice (in Polish), ZBU Intergeo Ltd., Mysłowice

Witkowski AJ (2016) Groundwater quality monitoring for the postexploitation phase of the municipal landfill site in Tychy-Urbanowice (in Polish). University of Silesia. Faculty of Earth Sciences. Sosnowiec, unpublished

Witkowski AJ (2017) Monitoring of the municipal waste landfills in Poland-legal requirements and reality. Hydrogeologia 1:49-56

Witkowski AJ, Dąbrowska D (2017) Diagnosis of the legal and organizational status of groundwater monitoring in Poland. Przegląd Geologiczny 65(11/2):1393-1397

Zdechlik R, Drzymała M, Wątor K (2013) Practical aspects of water sampling in groundwater monitoring (in Polish with English summary). Biuletyn Państwowego Instytutu Geologicznego 456:659-664 